\title{
DEVELOPMENT OF ADVANCED NOX CONTROL CONCEPTS FOR COAL-FIRED UTILITY BOILERS
}

DOE Contract No. DE-AC22-90PC90363

DOE/PC/90363-T4

Period of Performance: September 26, 1990 to October 26, 1992

DE92 017921

Quarterly Technical Progress Report No. 5

Period Covered by Report: October I to December 31, 1991

prepared by:
A. Evans
J. Newhall
G. England
W.R. Seeker

Energy and Environrnental Research Corporation

18 Mason

Ivvine, California 92718

Date Submitted: May 27, 1992

prepared for:

Mr. Charles E. Schmidt

U. S. Department of Energy

Pittsburgh Energy Technology Center

P. O. Box 10940

Pittsburgh, Pennsylvania 15236-0940

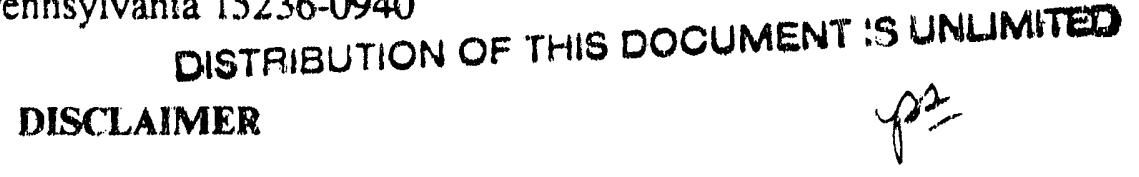

This report was prepared as an account of work sponsored by an agency of the United Situtes Government. Neither the United States Government nov atsy agency thereof, nor any of their employesus, makes any warsanty, express or impliod, or assumes any legal liability or responsibility for the accuracy, completeness. or usefulness of any information, apparatus, product, or process disclosed, or represents that its use would not infringe privately owned rights. Refer. ence herein to any specific commercial product, process, or service by trade name, Irademark, manufacturer: or otherwise does not hecessarily constitute or imply its endorsement. recommendation, or favoring by the United States Government of any agency thereof. 'The views and opinions of authors expressed herein do not nocessarily state or ceflect those of the United States Government or any agency thereof. 


\section{TABLE OF CONTENTS}

Section Page

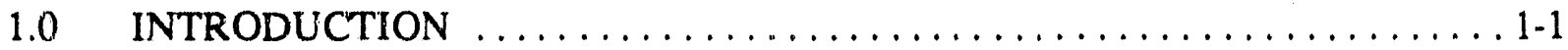

2.0 DEVELOPMENT OF IMPROVED NO/NO SAMPLING SYSTEM $\ldots \ldots \ldots 2-1$

2.1 MOTIVATION FOR STUDY $\ldots \ldots \ldots \ldots \ldots \ldots \ldots \ldots \ldots \ldots \ldots \ldots$

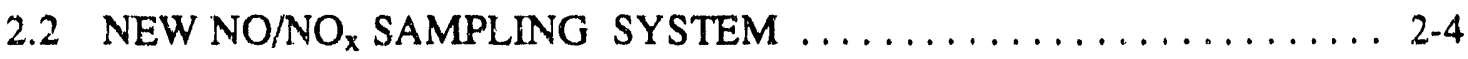

3.0 VALIDATION OF THE PROPOSED NO/NO $\mathrm{N}_{\mathrm{x}}$ SAMPLING SYSTEM $\ldots \ldots \ldots 3-1$

3.1 Accuracy Checks Using the Validation System $\ldots \ldots \ldots \ldots \ldots \ldots . . \ldots$ 3-1

3.1.1 Validation of Individual Components ............... 3-1

3.1.2 Validation of the Complete $\mathrm{NO} / \mathrm{NO}_{\mathbf{x}}$ Sampling System $\ldots \ldots . \quad 3-10$

3.2 Accuracy Checks with Actual Flue Gas $\ldots \ldots \ldots \ldots \ldots \ldots \ldots \ldots . \ldots \ldots$

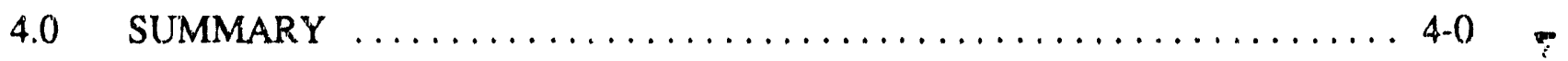




\section{LIST OF FIGURES}

Eigure

1-1 Application of $\mathrm{CombiNO}_{\mathrm{x}}$ to a wall-fired utility boiler $\ldots \ldots \ldots \ldots \ldots \ldots, 1-2$

2-1 Standard $\mathrm{NO} / \mathrm{NO}_{\mathrm{x}}$ sampling system schematic $\ldots \ldots \ldots \ldots \ldots \ldots \ldots \ldots, 2-2$

2-2 Ice bath water trap and permeation dryer systems schematic $\ldots \ldots \ldots \ldots \ldots .2-3$

2-3 Results from ice bath water trap and permeation dryer sampling systems $\ldots \ldots \ldots 2-5$

$2-4$ Proposed $\mathrm{NO} / \mathrm{NO}_{\mathrm{x}}$ sampling system $\ldots \ldots \ldots \ldots \ldots \ldots \ldots \ldots \ldots \ldots \ldots \ldots \ldots \ldots$

3-1 $\mathrm{NO} / \mathrm{NO}_{\mathrm{x}}$ sampling system validation set-up $\ldots \ldots \ldots \ldots \ldots \ldots \ldots \ldots \ldots .2$

3-2 $\mathrm{NO}_{2}$ to $\mathrm{NO}$ conversion with stainless steel contact $\ldots \ldots \ldots \ldots \ldots \ldots \ldots .7$

3-3 New $\mathrm{NO} / \mathrm{NO}_{\mathrm{x}}$ sampling system validation results $\ldots \ldots \ldots \ldots \ldots \ldots \ldots .14$

3-4 Performance of sampling systems with a $\mathrm{SO}_{2}$ doped natural gas fired flue gas . . 3-19

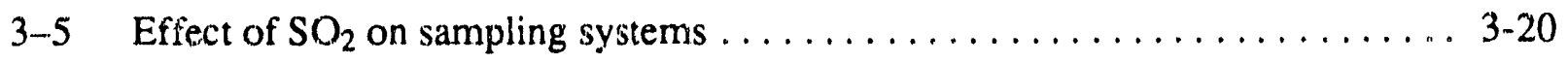

3-6 Performance of sampling systems with a coal fired flue gas $\ldots \ldots \ldots \ldots \ldots 3-22$

3-7 Effect of ash on $\mathrm{NO} / \mathrm{NO}_{\mathbf{x}}$ measurements in new sampling system $\ldots \ldots \ldots \ldots$ 3-23

$3-8$ Phase discrimination probe $\ldots \ldots \ldots \ldots \ldots \ldots \ldots \ldots \ldots \ldots \ldots \ldots \ldots \ldots \ldots, 24$

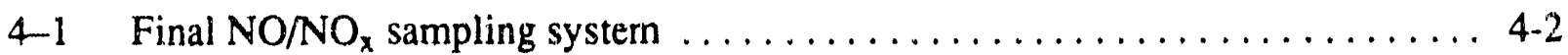




\section{LIST OF TABLES}

Table

3-1 Water trap validation data $\ldots \ldots \ldots \ldots \ldots \ldots \ldots \ldots \ldots \ldots \ldots \ldots, 3-4$

3-2 Teflon sample line validation data $\ldots \ldots \ldots \ldots \ldots \ldots \ldots \ldots \ldots \ldots \ldots . \ldots \ldots$

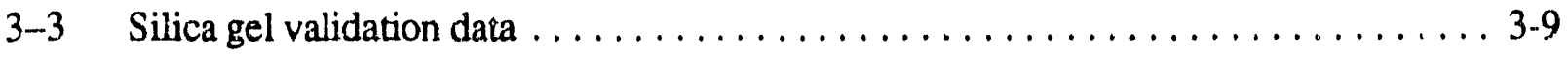

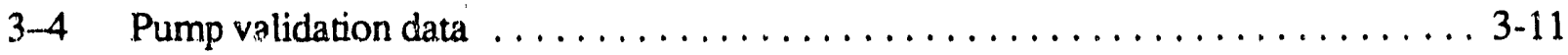

3-5 Filter validation data $\ldots \ldots \ldots \ldots \ldots \ldots \ldots \ldots \ldots \ldots \ldots \ldots \ldots \ldots, 11$

3-6 Complete system validation: larger chiller vs small chiller $\ldots \ldots \ldots \ldots \ldots \ldots, 3-12$

3-7 Effect of water vapor on new sampling system $\ldots \ldots \ldots \ldots \ldots \ldots \ldots \ldots, 3-15$

3-8 Effect of $\mathrm{NH}_{3}$ on new sampling system $\ldots \ldots \ldots \ldots \ldots \ldots \ldots \ldots \ldots \ldots, 16$, 
Hybrid technologies for the reduction of $\mathrm{NO}_{\mathrm{x}}$ emissions from coal fired utility boilers have shown the potential to offer greater levels of $\mathrm{NO}_{x}$ control than the sum of the individual technologies, leading to more cost effective emissions control strategies. Energy and Environmental Research Corporation (EER) has developed a hybrid $\mathrm{NO}_{x}$ control strategy involving two proprietary concepts which has the potential to meet the U.S. Department of Energy's $\mathrm{NO}_{\mathrm{x}}$ reduction goal at a significant reduction in cost compared to existing technology. The process has been named CombiNO . $^{-}$

CombiNO $_{x}$ is an integration of three technologies: modified reburning, promoted selective noncatalytic reduction (SNCR) and methanol injection. These technologies are combined to achieve high levels of $\mathrm{NO}_{x}$ emission reduction from coal fired power plants equipped with $\mathrm{SO}_{2}$ scrubbers. The first two steps, modified reburning and promoted SNCR are linked. It has been shown that performance of the SNCR agent is dependent upon local oxidation of CO. Reburning is used to generate the optimum amount of CO to promote the SNCR agent, although lower levels of reburning are needed than are traditionally applied in the reburning process. If the reburn fuel is natural gas, the combination of reburning and SNCR may result in a significant cost savings over conventional reburning. The third step, injection of methanol into the flue gas, is used to convert $\mathrm{NO}$ to $\mathrm{NO}_{2}$ which may subsequently be removed in a wet scrubber. Figure 1-1 illustrates how CombiNO ${ }_{x}$ may be applied to a coal fired utility boiler.

The overall objective of this program is to demonstrate the effectiveness of the CombiNO $\mathrm{x}_{\mathbf{x}}$ process at a large enough scale and over a sufficiently broad range of conditions to provide all of the information needed to conduct a full-scale demoristration in a coal fired utility boiler. The specific technical goals of this program are:

- $70 \% \mathrm{NO}_{\mathrm{x}}$ reduction at $20 \%$ of the cost of selective catalytic reduction;

- $\mathrm{NO}_{\mathrm{x}}$ levels at the stack of $60 \mathrm{ppm}$ for ozone non-attainment areas;

- Demonstrate use of coal reburning in CombiNO $x$ process;

- Identify all undesirable by-products of the process and their controlling parameters;

- Demonstrate $95 \% \mathrm{NO}_{2}$ removal in a wet scrubber. 


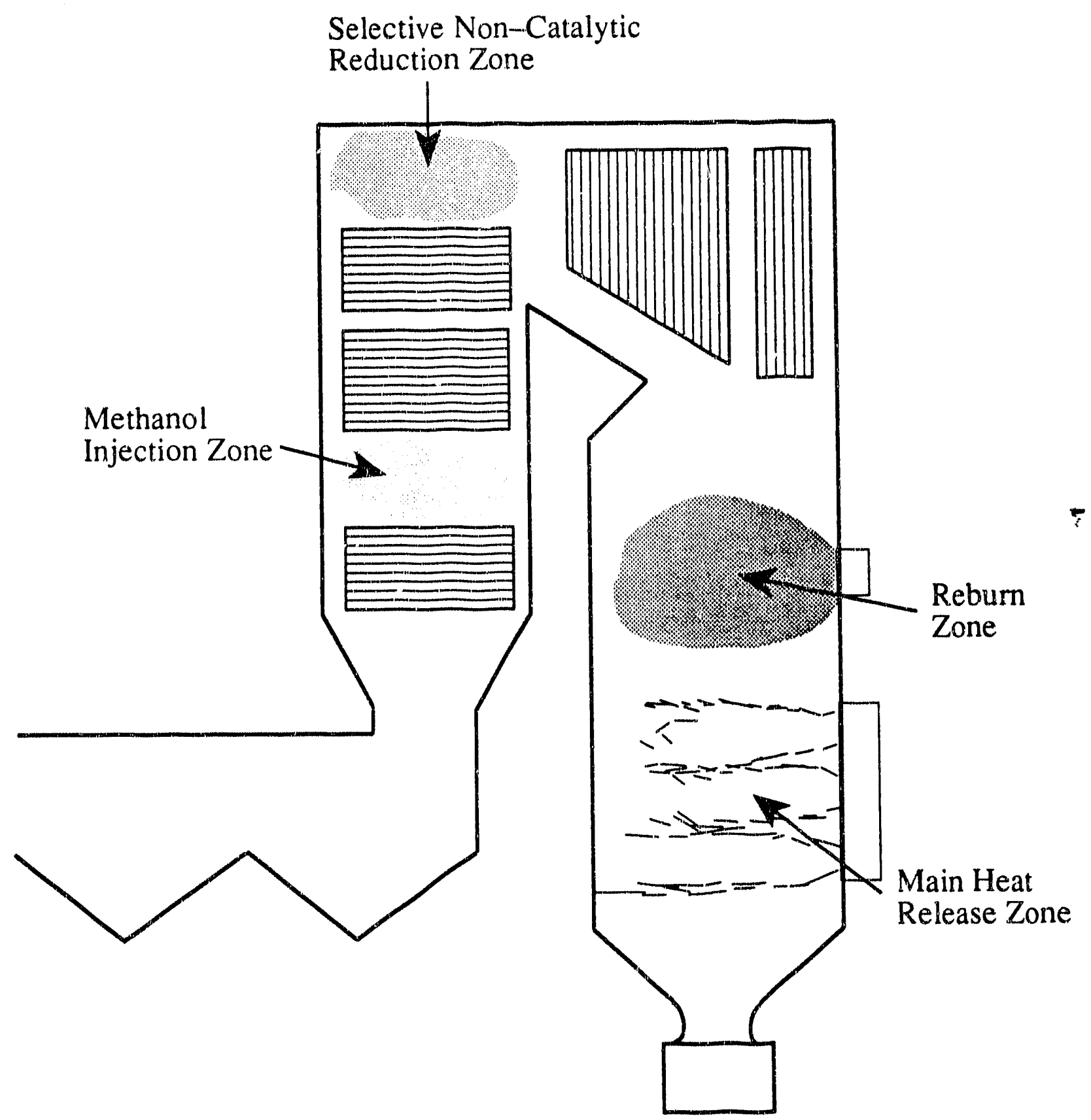

Figure 1-1. Application of CombiNO $\mathrm{X}_{\mathrm{x}}$ to a coal-fired utility boiler. 
To achieve these goals, the program was broken down into two experimental phases. The first phase is referred to as the Fundamental Studies Test Program. In this phase, each of the CombiNO ${ }_{x}$ steps will be analyzed individually at laboratory and pilot scales. In addition, the potential synergism between the three processes will be studied at pilot scale. Phase II is termed Process Studies. It is in this stage that scale-up issues will be addressed. Testing of the complete CombiNO $_{x}$ process will be performed in a $10 \mathrm{MMBtu} / \mathrm{hr}$ furnace which has been shown in the past to accurately simulate the thermal characteristics of a full scale utility boiler.

The primary objective during this reporting period was to clesign a $\mathrm{NO} / \mathrm{NO}_{\mathrm{x}}$ sampling system that would accurately measure $\mathrm{NO}$ and $\mathrm{NO}_{x}$ when large amou its of $\mathrm{NO}_{2}$ are present. This report will explain the problems associated with the standard $\mathrm{NO}^{2} \mathrm{SO}_{\mathrm{x}}$ sampling system, and describe the research performed towards the development of an improved system. 
During the pilot scale methanol injection tests, it was observed that $\mathrm{NO} / \mathrm{NO}_{\mathrm{x}}$ sampling problems exist when large amounts of $\mathrm{NO}_{2}$ are present. These problems are not apparent with most combustion sources of $\mathrm{NO}_{x}$ due to the low $\mathrm{NO}_{2}$ concentrations normally generated. In response to these sampling concerns, a new $\mathrm{NO} / \mathrm{NO}_{\mathrm{x}}$ sampling system was developed. This section will describe the motivation fur and the development of the improved sampling system.

\subsection{Motivation For Study}

The NO/NO ${ }_{x}$ sampling system typically used by EER on experimental facilities is shown in Figure 2-1. As illustrated, the system consists of a simple water knock-out (usually a Teflon or stainless steel coil and reservoir submerged in an ice bath), filter, and a Thermo Electron Corp. (TECO) Model $10 \mathrm{NO} / \mathrm{NO}_{\mathrm{x}}$ Analyzer. This system will be referred to as the "standard system". The TECO analyzer uses a chemiluminescent method for NO detection. This method exposes the dry gas sample to ozone; the ozone then reacts under vacuum with $\mathrm{NO}$ to form excited $\mathrm{NO}_{2}$ molecules. As the excited $\mathrm{NO}_{2}$ molecules relax to $\mathrm{NO}_{2}$, they produce a directly proportional amount of light photons. These photons are then measured by a photomultiplier tube providing a direct NO measurement. In order to measure total $\mathrm{NO}_{\mathbf{x}}$ (defined as $\mathrm{NO}+\mathrm{NO}_{2}$ ), the sample first passes through a converter which reduces any $\mathrm{NO}_{2}$ to $\mathrm{NO}$; the total $\mathrm{NO}_{\mathrm{x}}$ in the sample can then be determined as described above. $\mathrm{NO}_{2}$ can be determined from the difference of the $\mathrm{NO}$ and $\mathrm{NO}_{\mathrm{x}}$ measurements.

Since $\mathrm{NO}_{2}$ is water soluble, there was concern that it could be absorbed in the water collected in the ice bath water trap of the standard sampling system. To evaluate the efficiency of $\mathrm{NO}_{2}$ absorption in the water trap, a parmeation dryer system was used in parallel during a series of methanol injection tests conducted in September of 1991 on EER's Boiler Simulation Facility (BSF). A schematic of the duel gas conditioning system is shown in Figure 2-2. In the permeation dryer, the sample gas is passed through one side of a permeable membrane sleeve. Dry air passed on the other side of the sleeve removes moisture from the sample gas. 


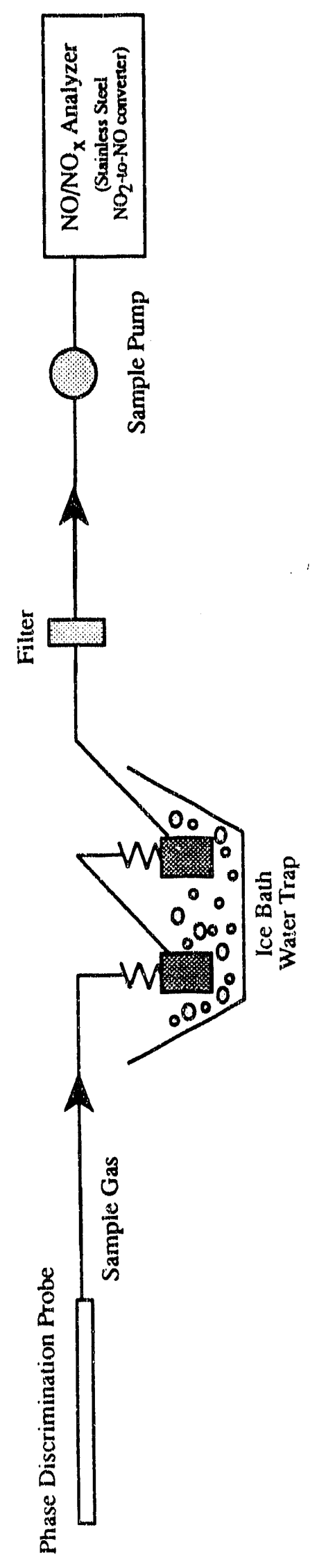

楚

हू हू

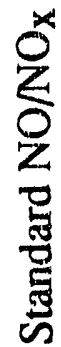

ن. 


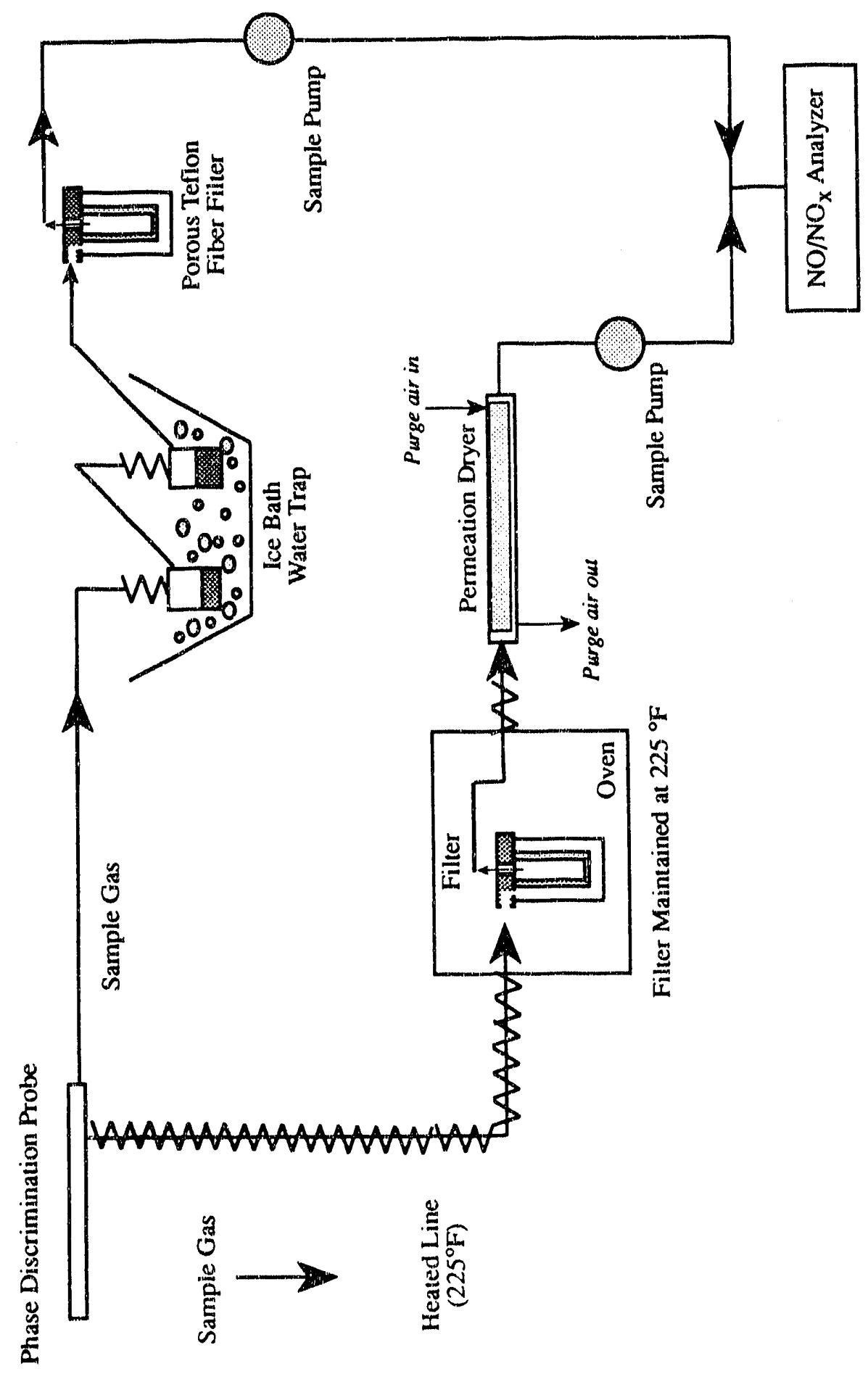

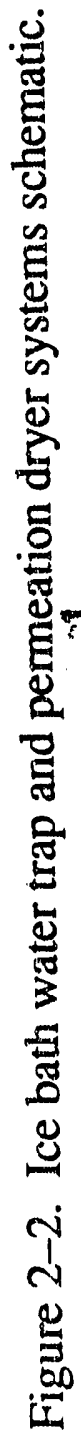


The results of an initial series of methanol injection tests are shown in Figure 2-3. In these tests, coal was fired resulting in an initial NO level of $950 \mathrm{ppm}$. The measurements performed with the two gas conditioning systems indicate that inaccuracies occur with both systems. First, both systems show a decrease in $\mathrm{NO}_{\mathrm{x}}$ suggesting that losses occur in the sampling system (since methanol injection is intended to convert NO-to- $\mathrm{NO}_{2}$, total $\mathrm{NO}_{\mathrm{x}}$ levels in the flue gas should remain constant throughout methanol injection). For the water trap system, it is hypothesized that most of the $\mathrm{NO}_{2}$ generated in the methanol step was absorbed in the water collected in the trap: The difference between $\mathrm{NO}_{\mathrm{x}}$ and $\mathrm{NO}$ measurements for the water trap system suggests that the absorption process is not 100 percent efficient. The decrease in $\mathrm{NO}_{\mathbf{x}}$ measured by the permeation dryer system is less than that observed with the water trap system; however, this $\mathrm{NO}_{\mathrm{x}}$ decrease indicates that losses also occur with the permeation dryer system.

The lack of agreement between NO measured with both conditioning systems suggests that another sampling artifact is being produced by one of the systems. At present, it is believed that, in the permeation dryer system, $\mathrm{NO}_{2}$ was converted to $\mathrm{NO}$ resulting in artificially high $\mathrm{NO}_{-}$ measurements. However, it is also possible that, in the water trap system, NO could be oxidized to $\mathrm{NO}_{2}$ at relatively cool temperatures associated with the cold sample lines and large chiller and subsequently absorbed in moisture in the sampling system. In any event, the results shown in Figure 2-3 made research into a reliable $\mathrm{NO} / \mathrm{NO}_{\mathrm{x}}$ sampling system for this project necessary.

\subsection{The New NO/NO Sampling System}

The primary objective of any gas sampling system is to deliver a properly conditioned gas sample to an analytical instrument or other measuring device. It is critical that the gas be conditioned in manner which does not influence the species of interest; otherwise the measurement will be in error. In order to obtain accurate $\mathrm{NO}_{2}$ measurements, the following considerations must be taken into account. 


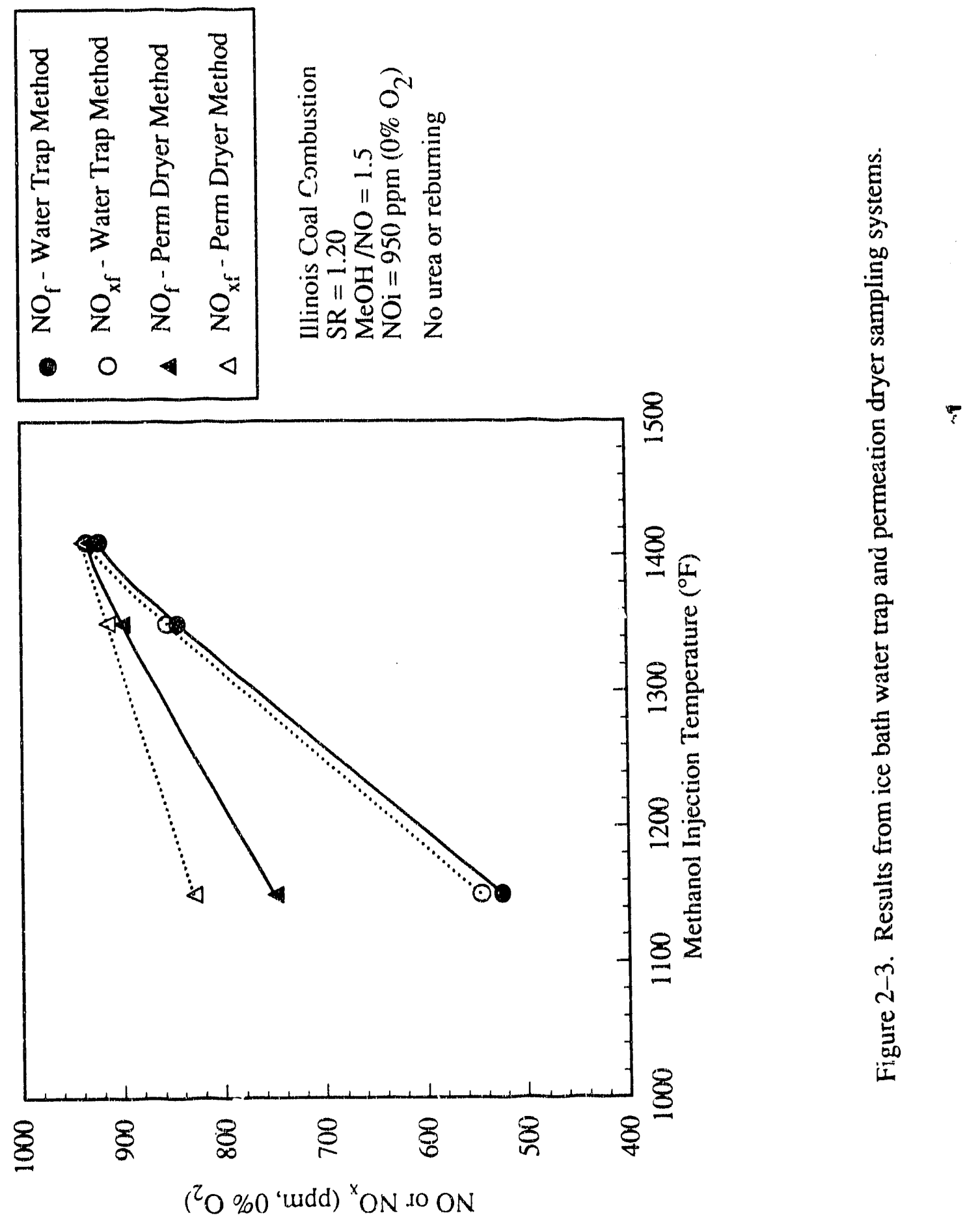




\section{Sampling System Considerations}

For sampling of $\mathrm{NO}$ and $\mathrm{NO}_{\mathrm{x}} \mathrm{s}_{\mathrm{p}}$ ecies, the gas sampling systern must consider the following four potential sources of error:

1. $\mathrm{NC}_{2}$ absorption into the condensed water within the ice bath water tran,

2. NO- $10-\mathrm{NO}_{2}$ conversion within the sample lines,

3. $\mathrm{NO}_{2}-\mathrm{to}-\mathrm{NO}$ conversion when in contact with stainless steel at high temperatures,

4. $\mathrm{NO}_{2}-\mathrm{to}-\mathrm{NO}$ conversion in the presence of fly ash.

The absorption of $\mathrm{NO}_{2}$ into the condensed water of the water trap is not a concern for NO measurements. Total $\mathrm{NO}_{\mathrm{x}}$ ineasurements , however, will be inaccurate if this artifact is not corrected. To avoid these losses of $\mathrm{NO}_{2}$ during $\mathrm{NO}_{\mathbf{x}}$ measurements, the $\mathrm{NO}_{\mathrm{x}}$ conversion $\left(\mathrm{NO}_{2}\right.$-to-NO) can be performed hefore the gas sample ever comes into contact with condensed water, therefore avoiding any loss due to absorption.

NO-to- $\mathrm{NO}_{2}$ conversion within the sample lines can be reduced if the lines are maintained at elevated temperatures and if residence times are minimized.

$\mathrm{NO}_{2}-\mathrm{t}$ - $\mathrm{NO}$ conversion catalyzed by the presence of stainless steel can be avoided by eliminating any stainless steel in the system where high temperatures will be reached. Quartz components and Teflon tubing and fittings can be substituted to eliminate this problem.

When burning coal, the resulting fly ash may contain activated carbon which is a known catalyst for $\mathrm{NO}_{2}$-to-NO conversion. For this reason, ash intake into the sample sysiem needs to be minimized. A quartz probe with a $90^{\circ}$ bend can be pointed downstream to slightly reduce such intake.

\section{Proposed Sampling System}

A modified sampling system was initially proposed as displayed in Figure 2-4. The stainless steel sample probe of the standard sampling system was replaced with a quartz probe to avoid stainless 

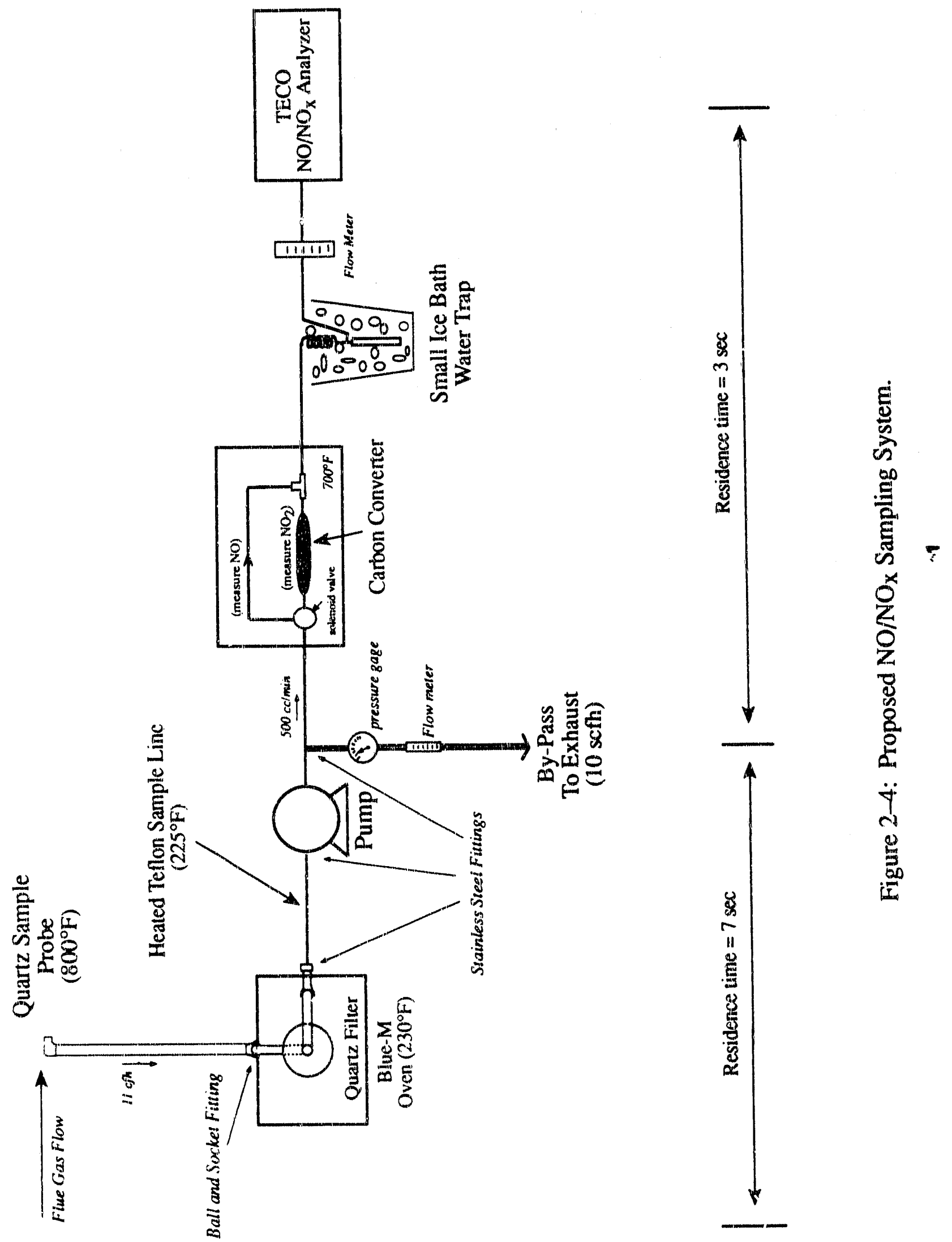
steel contact at high temperatures. The probe nozzle has a $90^{\circ}$ bend which can be pointed downstream to reduce particulate flow into the system.

The gas sample immediately passes through a glass fiber filter which is mounted on a glass frit inside a quartz filter housing. The complete filter set-up is housed inside a small Blue-M oven, which is used to maintain filter temneratures above $200^{\circ} \mathrm{F}$. 'These elevated temperatures help avoid condensation and resulting $\mathrm{NO}_{2}$ losses.

The gas sample is then transported into the control room by means of a heated Teflon sample line. Sample temperatures within the Teflon line are kept above $200^{\circ} \mathrm{F}$ to avoid condensation and to avoid NO-to- $\mathrm{NO}_{2}$ conversion. The Tetlon line is fitted with stainless steel fittings; this being the first stainless steel contact that the sample gas encounters. Temperatures are kept below $250^{\circ} \mathrm{F}$ to prevent the $\mathrm{NO}_{2}$--to-NO conversion that can occur with stainless steel contact. Subsequent components within the system use stainless steel fittings to avoid leakage problems that accompany Teflon and quartz fittings. Exposed stainless steel, however, is still kept at a minimum.

A diaphragm sample pump is the first component inside the control room, followed immediately by the carbon converter. The carbon converter (purchased from Rosomount Analytical) consists of a carbon-material-filled glass tube wrapped with a heating jacket. Conversion efficiency is optimum between the temperatures of $660^{\circ}$ to $750^{\circ} \mathrm{F}$, and flow rates through the converter must stay below $500 \mathrm{cc} / \mathrm{min}$. In order to accornmodate this flow rate limit and, at the same time, prevent a highly extended response time, a by-pass exhaust line is incorporated just prior to the carbon converter. An electronic switch is used to direct the flow either through or around the carbon converter, depending on whether a $\mathrm{NO}_{\mathrm{x}}$ or NO measurement is desired.

The carbon converter is followed by a water trap which consists of a spiral-formed stainless steel tube with a condensate-carching reservoir on the bottom. The trap is placed in an ice bath to condense out moisture present in the flue gas. The dry sample gas then enters a TECO Model 10 $\mathrm{NO} / \mathrm{NO}_{x}$ Analyzer.

It should be noted that all lines preceding the carbon converter are well heated and insulated to avoid condensation. All lines in general are kept as short as possible to minimize residence time. Total residence time for the complete system is approximately 10 seconds. 
Prior to performing measurements with the proposed system, a series of validation tests was conducted to verify its performance. These tests were performed using two separate approaches. Preliminary relative response tests were performed on a validation system that was designed just for this purpose. Real-time validation tests were also performed while sampling flue gas from a combustion tunnel.

\subsection{Accuracy Checks Using the Validation System}

A validation system was constructed that was capable of determining how the sample conditioning process influenced $\mathrm{NO}$ and $\mathrm{NO}_{2}$ concentrations. The general concept behind the system was to pass known amounts of $\mathrm{NO}$ and $\mathrm{NO}_{2}$ through the new sampling system and note any changes that occurred in the gas composition. This validation system is displayed in Figure 3-1. $\mathrm{NO}_{2}$ gas was ${ }^{7}$ formed for the procedure by introducing $\mathrm{NO}$ to $\mathrm{O}_{3}$; the $\mathrm{O}_{3}$ was supplied by passing $\mathrm{O}_{2}$ over an ultraviolet light source. Since it was not easy to set exact amounts of $\mathrm{NO}$ and $\mathrm{NO}_{2}$, a measurement comparison system was constructed.

Two identical lines were assembled in parallel between the span gas bottles and the TECO analyzer. One of the two lines had an opening in which a test component could be inserted. The test component could consist of either the whole sampling system or any combination of its components. By comparing $\mathrm{NO}$ and $\mathrm{NO}_{2}$ levels measured by the direct line to those measured by the test line, the influence of the test component on the gas composition was determined.

\subsubsection{Validation of Individual Components}

Before testing the system as a whole, individual components of the proposed system were tested to determine their effect on the $\mathrm{NO} / \mathrm{NO}_{2}$ composition. During these tests, the following problems 


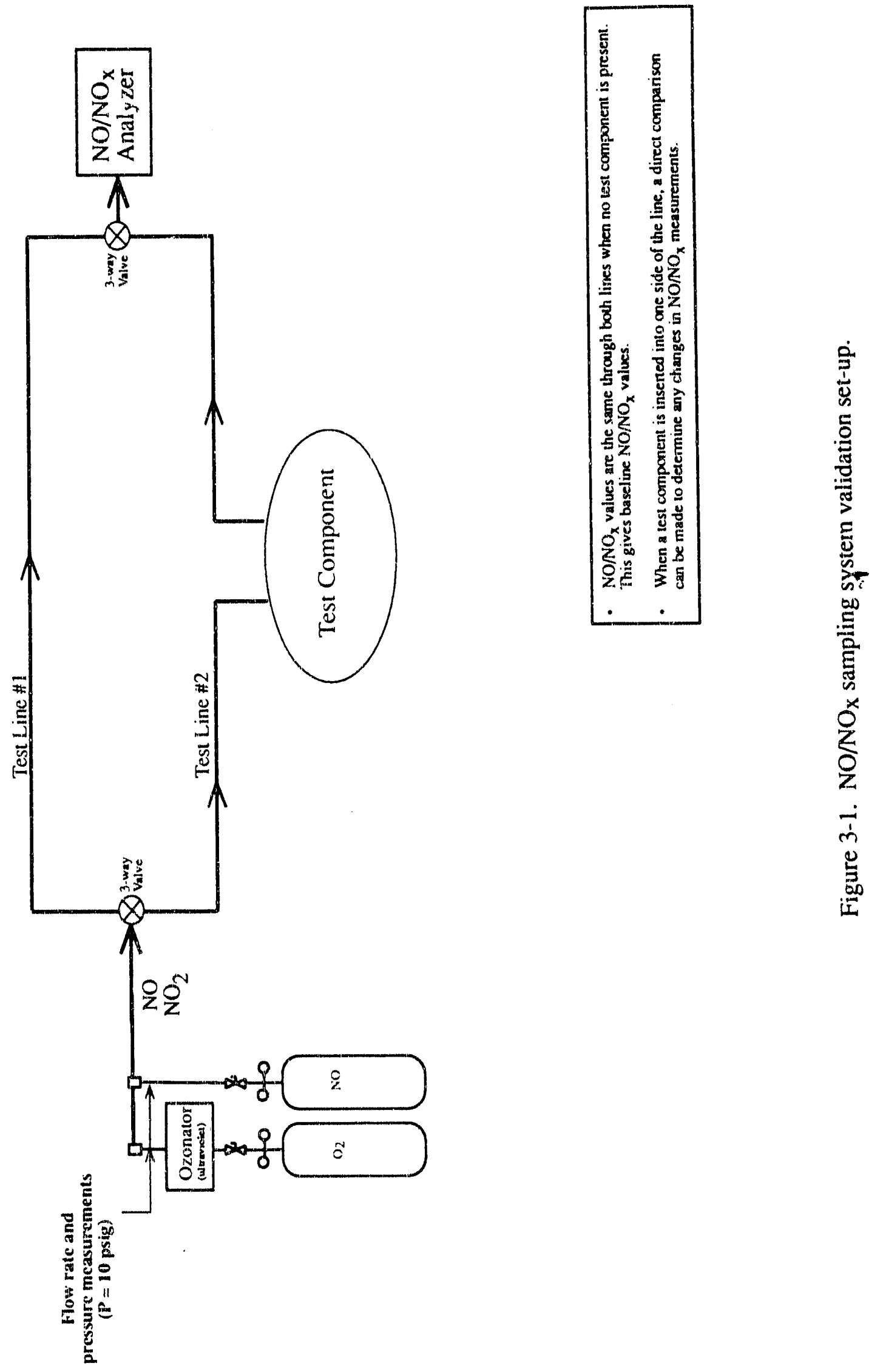


were addressed:

- NO to $\mathrm{NO}_{2}$ conversion within the water trap and sample lines,

- $\mathrm{NO}_{\mathrm{x}}$ losses within the water trap,

- $\mathrm{NO}_{2}$ to $\mathrm{NO}$ conversion in the presence of stainless steel,

- Silica Gel and Permeation Dryer water removal capabilities,

- the effect of the pump, sample line, and filter on $\mathrm{NO} / \mathrm{NO}_{\mathrm{x}}$ measurements.

The results of these tests are discussed below.

$\mathrm{NO}$ to $\mathrm{NO}_{2}$ Conversion Within the Ice Bath Water Trap and Sample Lines

According to chemical equilibrium and kinetics, $\mathrm{NO}_{2}$ is favored over $\mathrm{NO}$ at the cooler temperatures which are obtained in the unheated sample lines and ice bath water trap. For this reason, it was of interest to see how much conversion of NO-to- $\mathrm{NO}_{2}$ occurs within these components.

Table 3-1 displays the results as the water trap was tested in the validation set-up. Tests were run with and without $\mathrm{NO}_{2}$ present, as well as with and without water present. Residence time in the water trap is approximately 7 seconds.

The first set of data in the table contains no $\mathrm{NO}_{2}$ or water. As the dry $\mathrm{NO}$ and $\mathrm{O}_{2}$ sample passes through the water trap, approximately $4 \%$ of the $\mathrm{NO}$ is converted to $\mathrm{NO}_{2}$. The next set of data is taken under the same conditions except water is added to the water trap. The same conversion of NO-to- $\mathrm{NO}_{2}$ takes plact, however more loss of total $\mathrm{NO}_{x}$ occurs due to absorption of the newly formed $\mathrm{NO}_{2}$ into the water.

The last two sets of data in Table 3-1 pertain to samples containing both $\mathrm{NO}$ and $\mathrm{NO}_{2}$. The $\mathrm{NO}-$ to- $\mathrm{NO}_{2}$ conversion within the water trap was not as severe as the NO only case, perhaps due to the lower initial concentrations of NO. In this case, the addition of water into the system tended to increase the conversion of NO-to- $\mathrm{NO}_{2}$. 


\begin{tabular}{|c|c|c|c|c|}
\hline 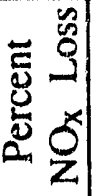 & $\frac{\stackrel{\circ}{\circ}}{0}$ & $\frac{\stackrel{9}{*}}{+}$ & $\stackrel{8}{\circ}$ & $\frac{50}{m}$ \\
\hline 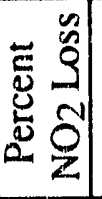 & 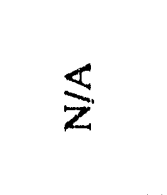 & $\frac{\Sigma}{z}$ & $\stackrel{\circ 0}{\stackrel{2}{r}}$ & 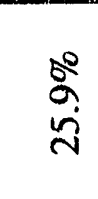 \\
\hline 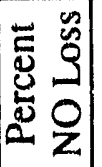 & $\begin{array}{l}0 \\
i n\end{array}$ & $\begin{array}{l}\stackrel{8}{\infty} \\
\dot{\forall}\end{array}$ & $\begin{array}{l}\stackrel{\circ}{\circ} \\
\text { i }\end{array}$ & $\begin{array}{l}50 \\
\infty \\
0\end{array}$ \\
\hline 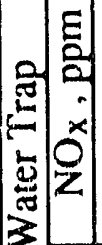 & గ్ & $\sqrt[n]{6}$ & 82 & $\overline{0}$ \\
\hline 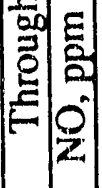 & $\frac{n}{6}$ & ఫ్ర & $\mathscr{Z}$ & $\stackrel{9}{\dot{y}}$ \\
\hline 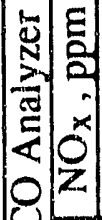 & $\stackrel{\infty}{\infty}$ & $\tilde{\infty}$ & 8ิ & 8 \\
\hline 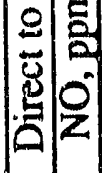 & $\mathscr{\infty}$ & ర్ర & $\begin{array}{l}\mathscr{\sigma} \\
\forall\end{array}$ & $\bar{F}$ \\
\hline 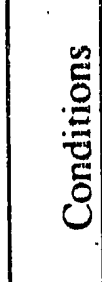 & 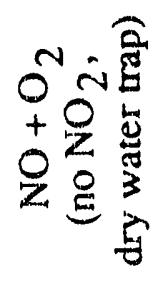 & 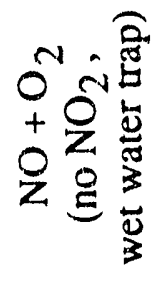 & 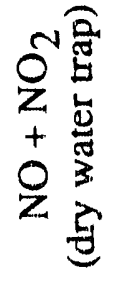 & 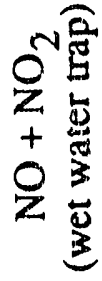 \\
\hline
\end{tabular}


Since the $\mathrm{NO}-$ to- $\mathrm{NO}_{2}$ conversion is more apt to occur at cooler temperatures, the use of a heated sample line (as opposed to a non-heated line) should reduce these conversions. Table 3-2 compares $\mathrm{NO}$ and $\mathrm{NO}_{\mathrm{x}}$ losses for both a heated and unheated Teflon sample line. $8.1 \%$ conversion of NO-to- $\mathrm{NO}_{2}$ takes place when the sample line is cold, as compared to only $1.8 \%$ when the line is heated $\left(230^{\circ} \mathrm{F}\right)$. Therefore, the heated line is beneficial not only for reasons of preventing condensation, but also in terms of reducing unwanted conversions. Note that, as would be expected, very little total $\mathrm{NO}_{\mathrm{x}}$ is lost within the sample line in either case.

\section{NO $O_{x}$ Losses Within the Water Trap}

The ability of $\mathrm{NO}_{2}$ to absorb into water is a known phenomenon, and it is this concept that initially prompted this study into an alternative sampling system for measurements of high $\mathrm{NO}_{2}$. Referring back to Table 3-1, the last set of data shows that $25 \% \mathrm{NO}_{2}$ loss occurs when water is present within the water trap. In order to reduce these losses, residence time in the water trap was reduced from 7 to 3 seconds by decreasing its size. Results from these tests will be discussed in Section 3.1.2. Slight $\mathrm{NO}_{\mathrm{x}}$ losses still occurred, but never more than $5 \%$. Further research into a better water removal method may be desired in the future.

$\mathrm{NO}_{2}-$ to-NO Conversion in the Presence of Stainless Steel,

Stainless steel is a known catalyst for the conversion of $\mathrm{NO}_{2}-$ to-NO (stainless steel is used in the TECO analyzer specifically for this conversion). Since stainless steel is often used for fittings and components within sampling systems, it was of interest to see at which temperatures these conversions occur. An experiment was performed in which $\mathrm{NO}$ and $\mathrm{NO}_{2}$ gases were sent through a two foot long, heated $1 / 8$ " stainless steel tube. The temperature was increased from ambient to $500^{\circ} \mathrm{F}$, and $\mathrm{NO} / \mathrm{NO}_{\mathrm{x}}$ ineasurements were taken throughout. The results are displayed in Figure 3-2. Two different runs were performed, and two different results were obtained.

The first run showed that almost all of the $\mathrm{NO}_{2}$ present in the gas was converted to NO before the tube reached $400^{\circ} \mathrm{F}$. This would indicate that care should be taken when using stainless steel at high temperatures. The second run, performed exactly like the first, demonstrated that some, but not much, of the $\mathrm{NO}_{2}$ converted to $\mathrm{NO}$. It is known that the catalytic reaction will only occur if the 


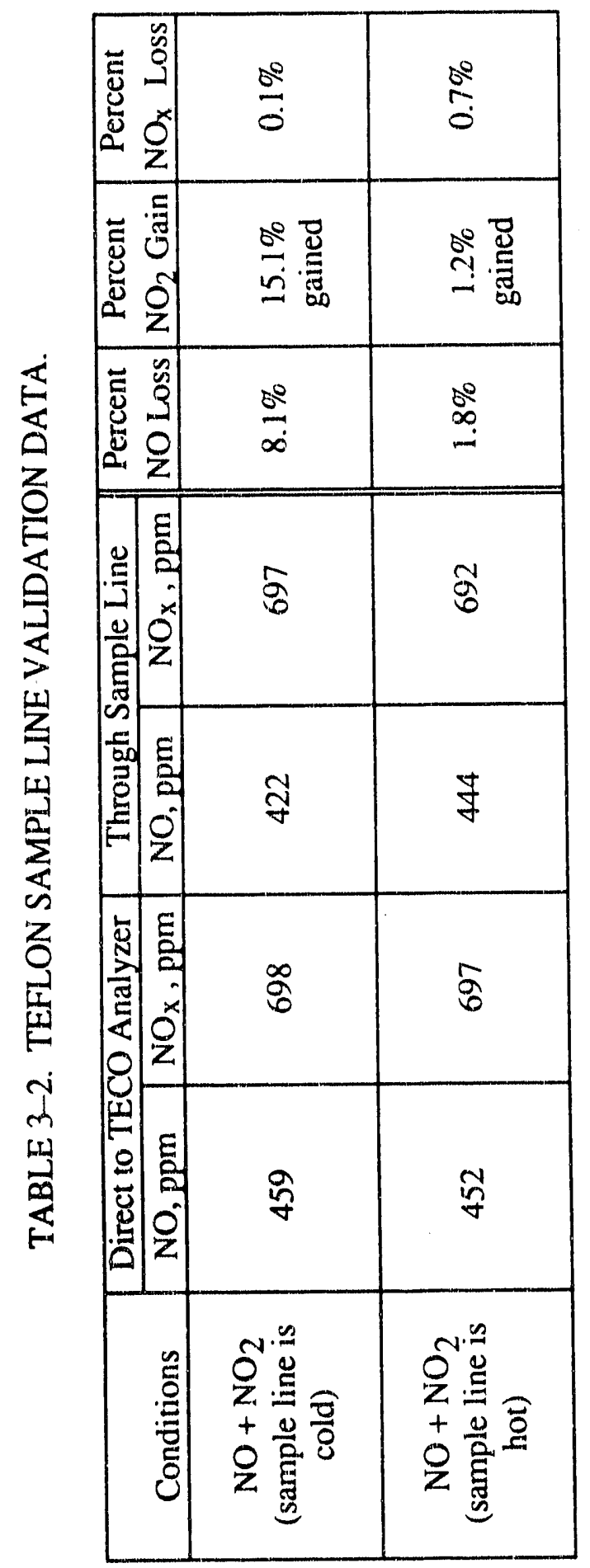




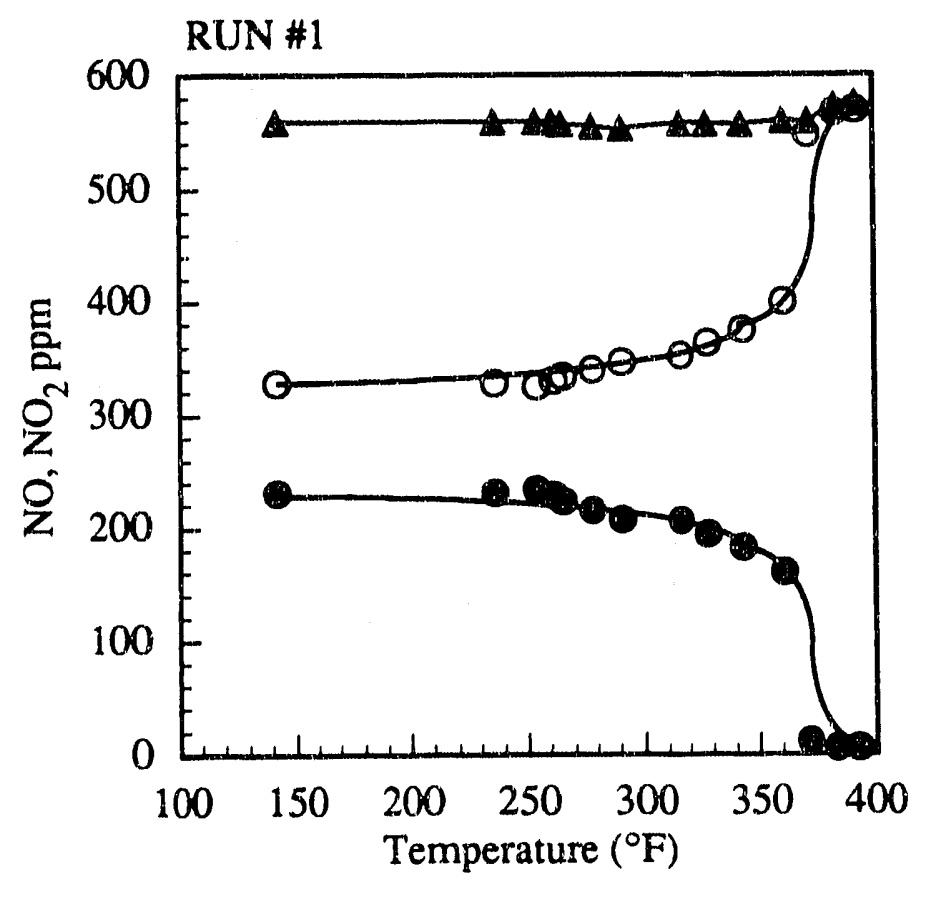

Bench Scale tests

$\mathrm{NO}, \mathrm{O}_{2}, \mathrm{NO}_{2}$ (formed from ozone) passed througn stainless steel tube. Temperature increased from ambient to $400-500^{\circ} \mathrm{F}$

$\mathrm{NOi}=329 \mathrm{ppm}$

$\mathrm{NO}_{2} \mathrm{i}=321 \mathrm{ppm}$

Residence time $=.2 \mathrm{sec}$

$$
\begin{aligned}
& \text { - } \mathrm{NO} \\
& -\mathrm{NO}_{2} \\
& \Delta \mathrm{NO}_{\mathrm{x}}
\end{aligned}
$$

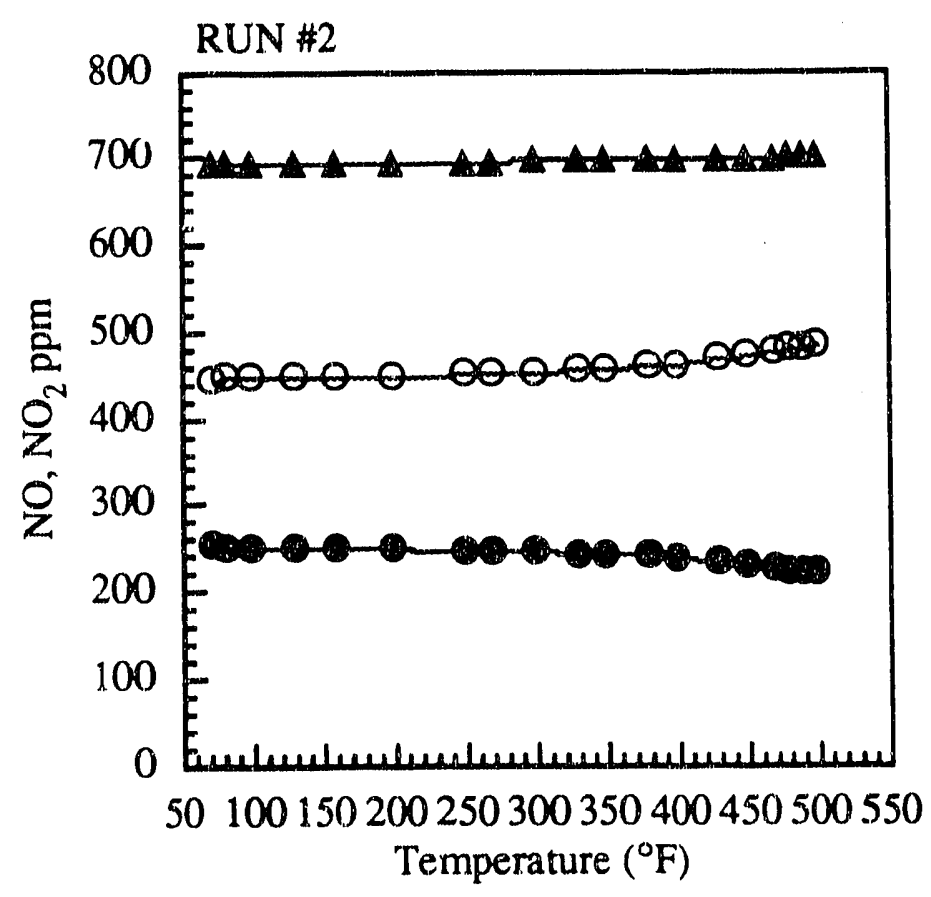

$$
\begin{aligned}
& -\mathrm{NO} \\
& \mathrm{NO}_{2} \\
& -\mathrm{NO}_{x}
\end{aligned}
$$

1 igure 3-2. $\mathrm{NO}_{2}$ to $\mathrm{NO}$ conversion with stainless steel contact. 
stainless steel surface is well oxidized. It is hypothesized that the oxidation condition of the tube was inconsistent between the two runs, resulting in less conducive conditions for $\mathrm{NO}_{2}-$ to- $\mathrm{NO}$ conversion during the second run.

Validation checks for the sample system will be performed while using stainless steel fittings at locations where temperatures are kept below $250^{\circ} \mathrm{F}$. Figure 3-2 demonstrates that these temperatures should be safe from $\mathrm{NO}_{2}$-to-NO conversions.

\section{Alternate Water Removal Systems}

Since large $\mathrm{NO}_{\mathrm{x}}$ losses occur within the current water removing device, two other methods of removing water were considered. Silica gel and a permeation dryer were tested in the validation set-up.

Silica gel is a moisture removing desiccant that is commonly used in combination with other water removal methods as a reinforcer. Since the sample flow rates entering the $\mathrm{NO}_{\mathrm{x}}$ analyzer are so low for the new sampling system (due to carbon converter restrictions), the possibility of using silica gel to remove moisture was considered. A 3/8" Teflon tube filled with silica gel was tested in the validation set-up. Results (displayed in Table 3-3) showed that the silica gel removed all $\mathrm{NO}_{2}$ and $29 \%$ of the NO present in the gas sample. This demonstrates that silica gel is not an appropriate water removal method for $\mathrm{NO}_{\mathrm{x}}$ measurement systems.

The permeation dryer is a water removal device that consists of a permeable membrane through which only water is intended to pass. A counter-flow stream of dry air is used to purge the water vapor from the sample stream through the permeable membrane. The purge gas flow rate must stay greater than that of the sample gas. This will keep the partial pressure of the water within the sample stream greater than that within the purging stream, forcing the water vapor through the membrane into the purging gas.

Suspicions of measurement inaccuracies associated with the permeation dryer (similar to those discussed in Section 2.0) motivated investigation of this water removal technique. The results show that the permeation drye normally used on site had a tendency to convert $\mathrm{NO}_{2}$-to-NO. Specialized 


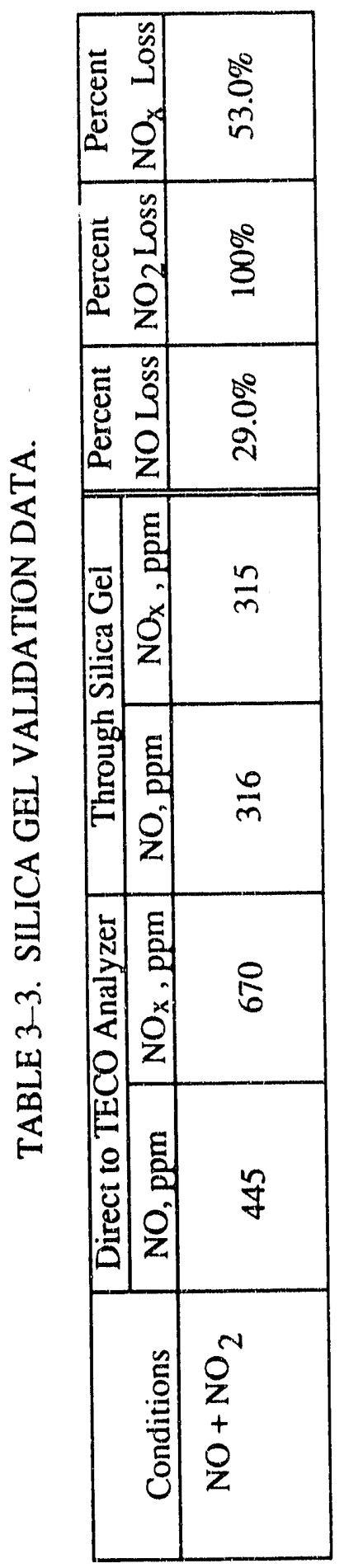


permeation dryers recommended for $\mathrm{NO}_{\mathrm{x}}$ measurements are available and should be tested for accuracy in the future.

\section{Validation Check of Pump and Filter}

Both the purnp and the filter were tested to determine their effects on the $\mathrm{NO} / \mathrm{NO}_{2}$ composition. Table 3-4 displays the results obtained while testing the sample pump under both ambient and elevated temperatures. During sampling, the pump must be heated in order to prevent condensation. Both cases showed little effect on $\mathrm{NO} / \mathrm{NO}_{\mathrm{x}}$ measurements.

The influence of the filter was tested by means of comparing the results of the complete system with and without the filter on line. Results are displayed in Table 3-5. The filter proved to have no effect on the $\mathrm{NO} / \mathrm{NO}_{x}$ measurements.

\subsubsection{Validation of the Complete $\mathrm{NO} / \mathrm{NO}_{\mathrm{x}}$ Sampling System}

The final step was to validate the complete $\mathrm{NO} / \mathrm{NO}_{\mathbf{x}}$ sampling system. This procedure was also performed on the validation system displayed in Figure 3-1. It should be noted that when measuring $\mathrm{NO}_{\mathrm{x}}$ through the sampling system, the carbon converter was used for the $\mathrm{NO}_{2}-$ to-NO conversion, in lieu of the TECO's stainless steel converter (as used for the direct line measurernents). Depending upon converter efficiencies, $\mathrm{NO}_{\mathrm{x}}$ values may vary slightly between the two test lines.

It also should be noted that stainless steel fittings are used for these validation tests in locations where temperatures will remain below $250^{\circ} \mathrm{F}$. A close watch for any conversions of $\mathrm{NO}_{2}-$ to-NO due to this stainless sinel will be conducted.

The first tests of the complete system were performed using the large water trap that was proved inaccurate for $\mathrm{NO} / \mathrm{NO}_{\mathrm{x}}$ measurements. In Table 3-6, these results are compared to those obtained with the new, reduced residence time, water trap. The new water trap yielded more accurate results than the old, larger volume water trap in terms of $\mathrm{NO}$-to- $\mathrm{NO}_{2}$ conversion as well as $\mathrm{NO}_{2}$ losses. 

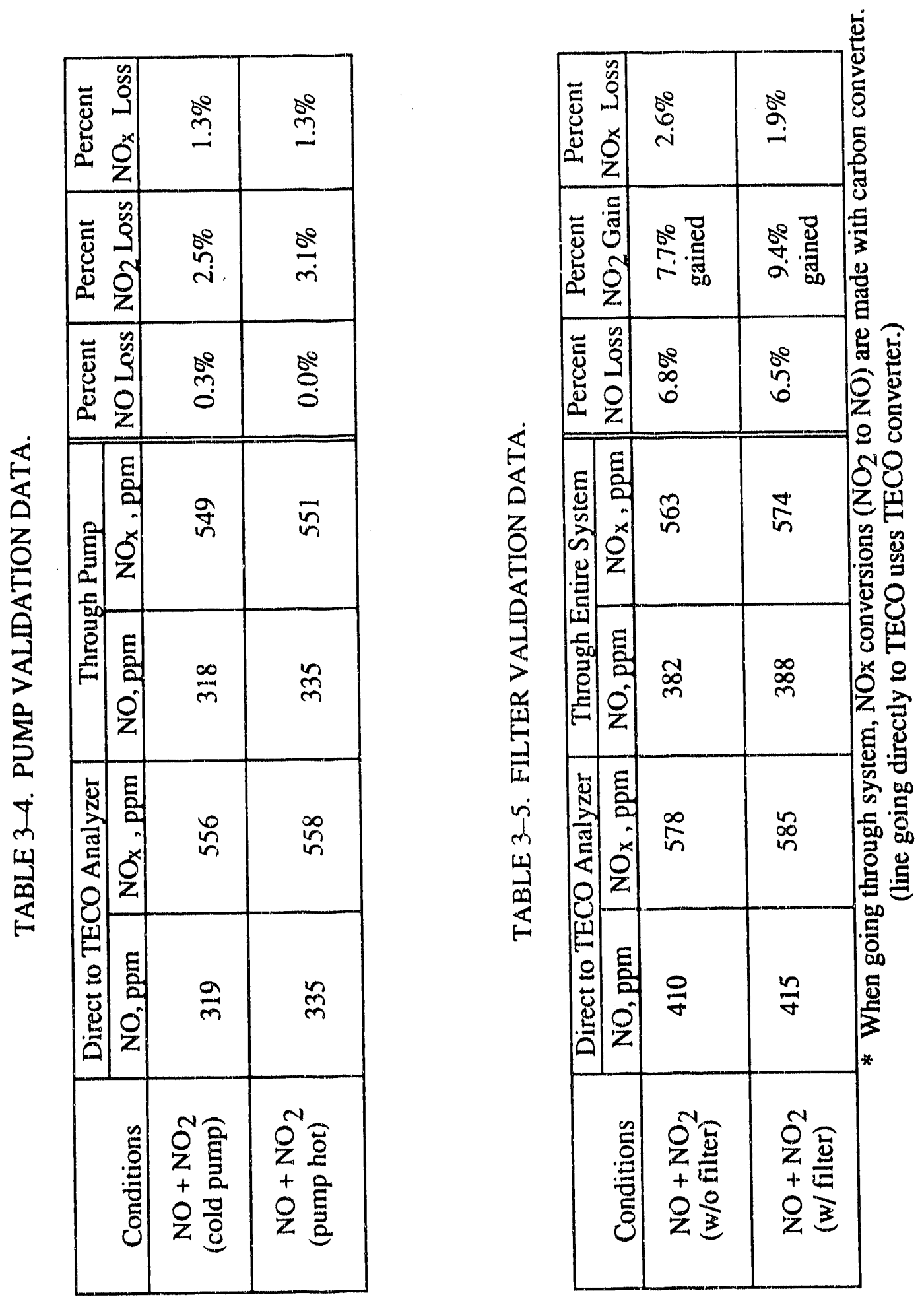


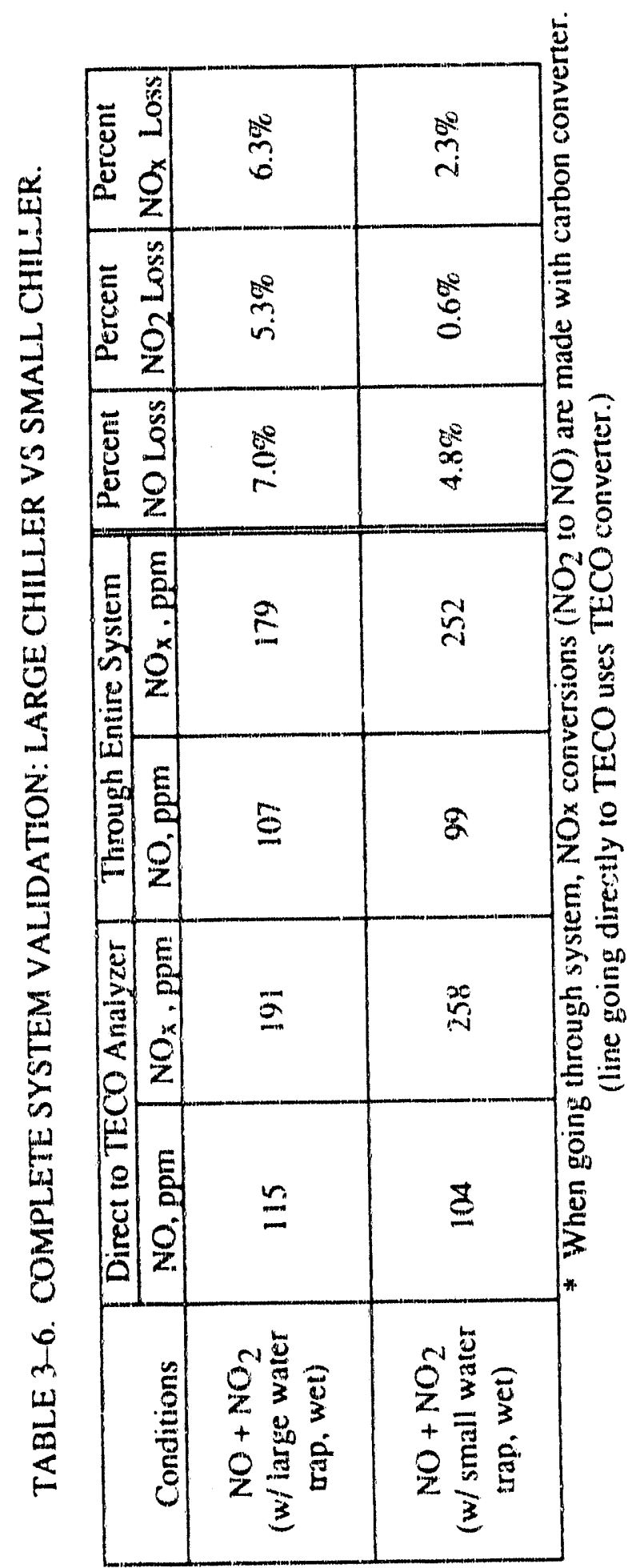


Using the new water trap and assuring all conditions to be as if actually testing (i.e., all lines heated above dew point and water present in the water trap), the complete system was ready for validation. The results are displayed in Figure 3-3. For dry $\mathrm{NC}, \mathrm{NO}_{2}$ and $\mathrm{O}_{2}$ gases passing through the new sampling system, an average of $95 \%$ NO recovery was obtained. NO concentrations were varied between $104 \mathrm{ppm}$ and $407 \mathrm{ppm}$; percent recovery did not appear to be dependant upon NO concentration.

The presence of stainless steel fittings within the system did not seem to initiate the catalytic $\mathrm{NO}_{2}$-to-NO conversion. $\mathrm{NO}_{2}$ recovery was very successful.

\section{Effect of Water Vapor}

Since the water removal step of the sample conditioning process results in large $\mathrm{NO}_{\mathrm{x}}$ losses, it was important to validate the system with water present in the sample. Steam was generated with the use of a syringe pump and stainless steel tubing that was heated to vaporizing temperatures. $20 \%$ molar ratio of steam to simulated flue gas was injected. The results, displayed in Table 3-7, indicate that, even with water present in the system, approximately $95 \% \mathrm{NO}$ and even higher $\mathrm{NO}_{\mathrm{x}}$ was recovered.

\section{Effect of $\mathrm{NH}_{3}$}

The effect of ammonia on $\mathrm{NO}_{\mathrm{x}}$ measurements was of interest because ammonia is known to partially o.sidize to NO in the presence of stainless steel at high temperatures (hence concern with the TECO's stainless steel converter which operates at $1200^{\circ} \mathrm{F}$ ). The results of the ammonia tests are displayed in Table 3-8. When ammonia is added, $15 \%$ dilution orcurs due to the ammonia carrier, $\mathrm{N}_{2}$. The addition of $130 \mathrm{ppm}$ of $\mathrm{NH}_{3}$ into the system only seems $\mathrm{o}$ affect $\mathrm{NO}$ by means of dilution; no $\mathrm{NH}_{3}$-to-NO conversion appears to be taking place. However, due to materials within the $\mathrm{NO}_{x}$ converters, $\mathrm{NO}_{x}$ measurements became inconsistent when high levels of ammonia were present. 

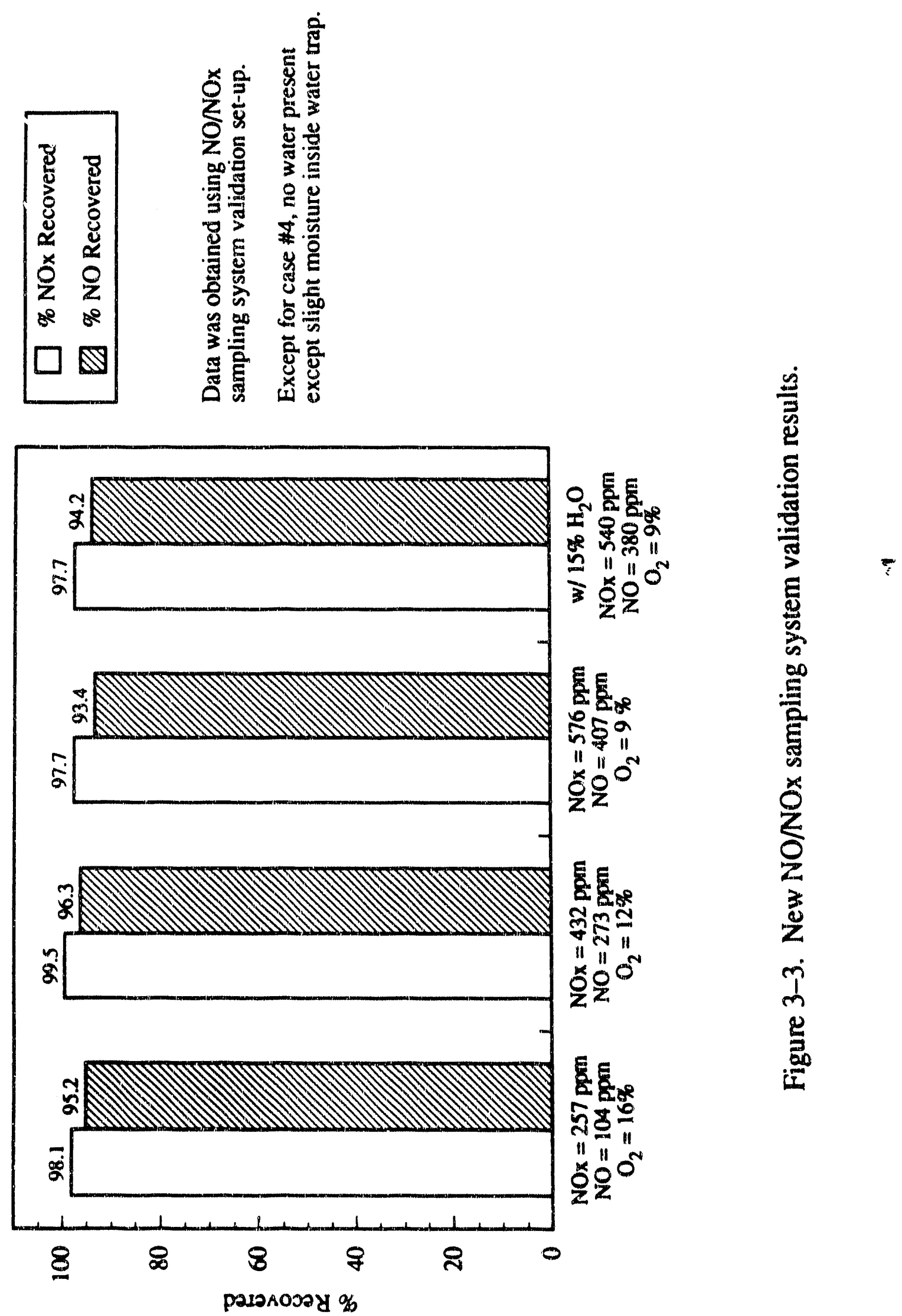


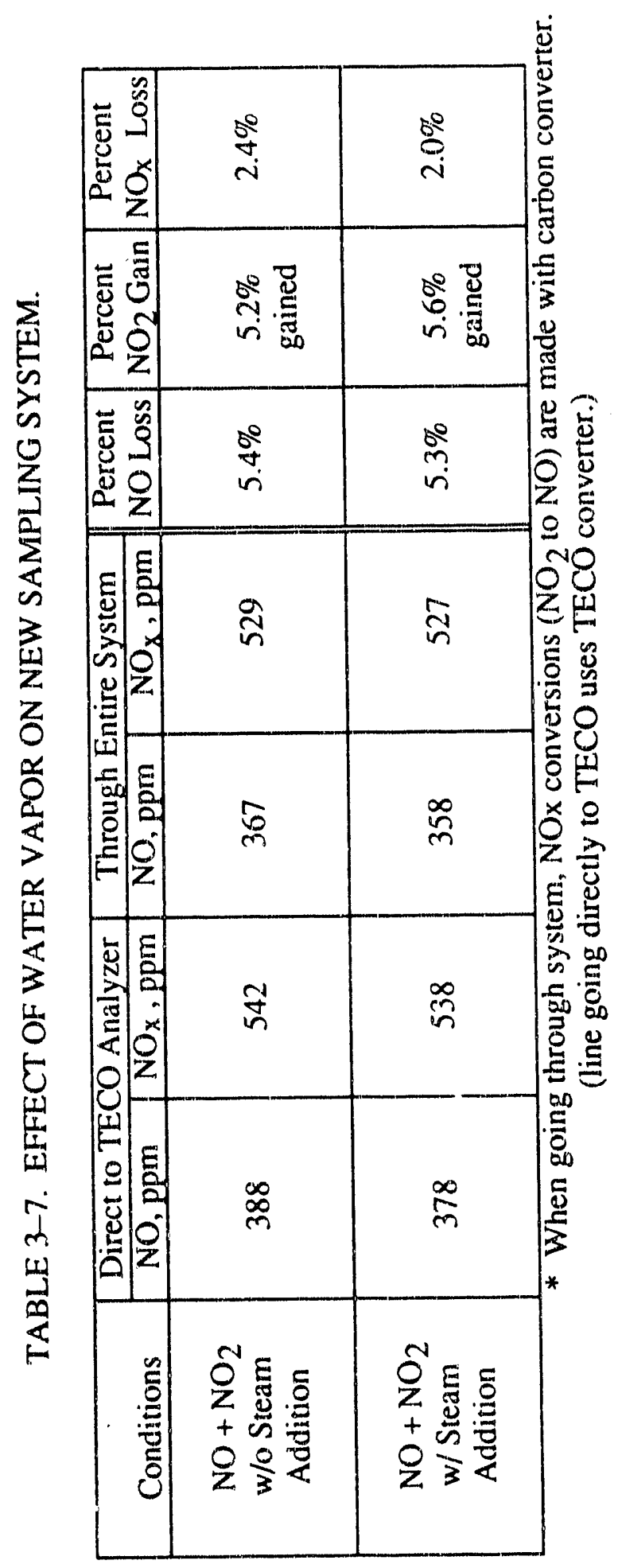




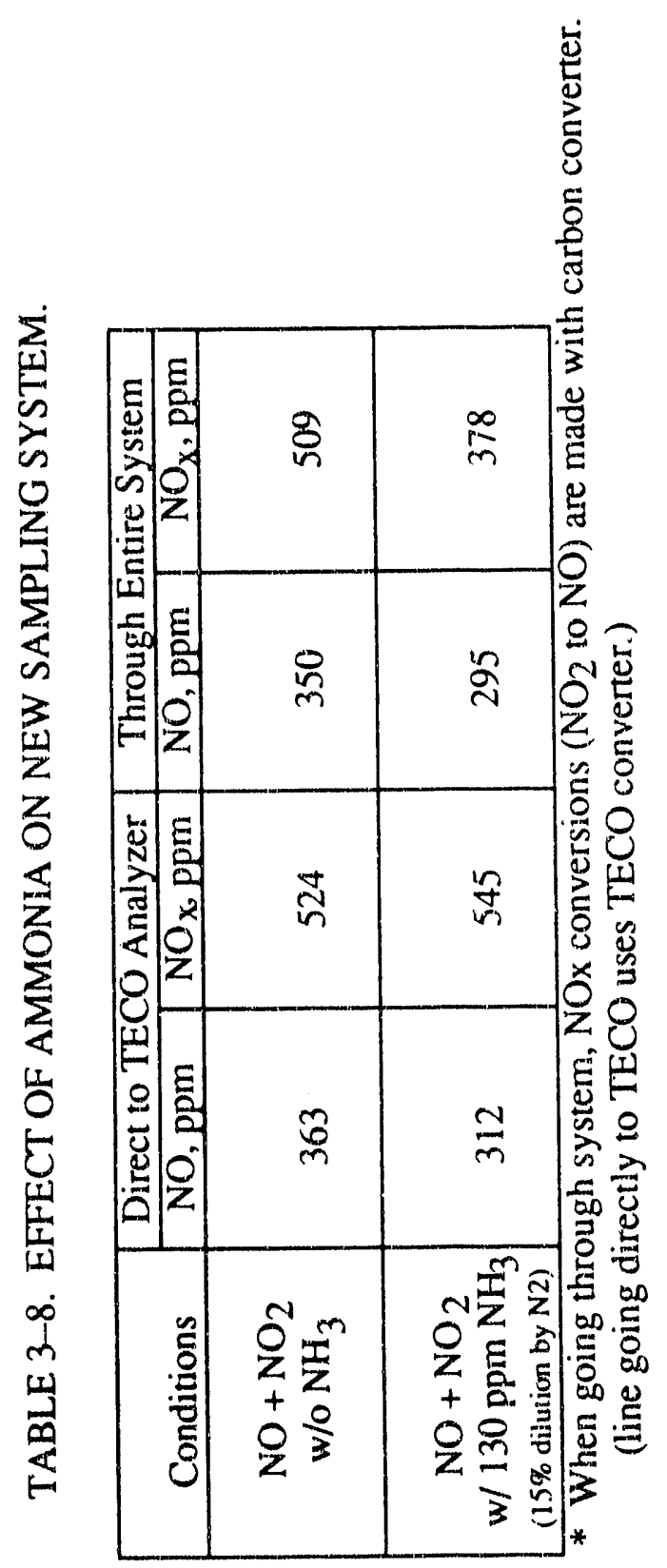


When the sample is passed directly to the TECO Analyzer, the stainless steel converter is used to convert $\mathrm{NO}_{2}-$ to- $\mathrm{NO}$ for the $\mathrm{NO}_{\mathrm{x}}$ measurements. Using this converter, the $\mathrm{NO}_{\mathrm{x}}$ measurement was larger for the case with $\mathrm{NH}_{3}$ present than that without $\mathrm{NH}_{3}$ present. This suggests that a $\mathrm{NH}_{3}$-to-NO conversion is taking place. The stainless steel converter is not recommended for high ammonia conditions; all ammonia should be removed prior to the converter. It should be noted that the stainless steel within the sample system itself does not appear to be at a high enough temperature for a long enough residence time to encourage the $\mathrm{NH}_{3}$-to-NO conversion.

As the sample passes through the sampling system, the carbon converter is responsible for converting $\mathrm{NO}_{2}$-to-NO for the $\mathrm{NO}_{\mathrm{x}}$ measurements. This type of converter also promotes problems in an ammonia rich environment. Total $\mathrm{NO}_{\mathrm{x}}$ was found to decrease as the ammonia was passed through the carbon converter. In the presence of activated carbon, $\mathrm{NO}$ and $\mathrm{NH}_{3}$ can reduce to molecular nitrogen; the carbon within the converter could be responsible for such a reaction. Again, it is advisable that $\mathrm{NH}_{3}$ be scrubbed before entering the carbon converter. At conditions near optimum, CombiNO ${ }_{x}$ has produced very low amnonia slip levels, therefore these conversions should not be a problem for this project.

\subsection{Accuracy Checks with Actual Flue Gas}

While CombiNO ${ }_{x}$ tests were being performed on the BSF, both the standard and new sampling systems were used in parallel so that a reference was always available. Methanol injection was being performed so that high levels of $\mathrm{NO}_{2}$ were present. The results are as follows.

\section{Natural Gas Fired Flue Gas}

The two sampling systems agreed on NO measurements throughout the methanol injection tests that were performed while burning natural gas on the BSF. $\mathrm{NO}_{2}$ was not lost within the new sampling system as it was with the old. For the new system, total $\mathrm{NO}_{\mathrm{x}}$ remained constant throughout the methanol injection procedure as was expected. 
Since NO measurments were in agreement between the two sampling systems throughout the methanol injection, it can be concluded that the stainless steel probe on the old system had no effect on $\mathrm{NO} / \mathrm{NO}_{\mathrm{x}}$ measurements; i.e., no $\mathrm{NO}_{2}-$ to-NO conversions occurred. This could be because the walls of the stainless steel sample probe stay fairly cool due to the water cooling jacket, thus preventing the conversions from occurring. Another explanation could be the loss of the stainless steel oxidation that was discussed earlier. A switch back to stainless steel may be desirable (for low ammonia systems) due to its durability and ease of use as compared to the quartz probe.

\section{Ncitural Gas Fired Flue Gas Doped With $\mathrm{SO}_{2}$}

$\mathrm{SO}_{2}$ was not thought to be an interference on the $\mathrm{NO}_{x}$ sampling system until a disparity between measurements was noted during CombiNO ${ }_{x}$ 's pilot scale tests. When 3000 ppm of $\mathrm{SO}_{2}$ was doped into a natural gas fired system (performed to determine the effect of $\mathrm{SO}_{2}$ on methanol's $\mathrm{NO}$-to- $\mathrm{NO}_{2}$ conversion), a discrepancy between the standard and new $\mathrm{NO}_{\mathbf{x}}$ sampling systems was detected (see Figure 3-4). The two systems began disagreeing when high levels of $\mathrm{NO}_{2}$ and $\mathrm{SO}_{2}{ }^{7}$ were simultaneously present. A validation test was performed to determine which sampling system was sensitive to the high levels of $\mathrm{SO}_{2}$.

The validation test consisted of injecting $3000 \mathrm{ppm}$ of $\mathrm{SO}_{2}$ into the furnace immediately upstream of the sample probe $\left(\approx 400^{\circ} \mathrm{F}\right)$ under high $\mathrm{NO}_{2}$ conditions $\left(\mathrm{NO}_{2}\right.$ obtained with methanol injection). Injecting the $\mathrm{SO}_{2}$ at this temperature should avoid any interferences with the methanol injection reactions, yet any sampling system interferences would be detected. NO and $\mathrm{NO}_{\mathrm{x}}$ measurements were taken with both systems before and after injecting the $\mathrm{SO}_{2}$. Figure 3-5 shows that the standard sampling system detected a $\mathrm{NO}$ interference when the $\mathrm{SO}_{2}$ was injected. A possible explanation is the oxidation of $\mathrm{SO}_{2}$ to $\mathrm{SO}_{3}$ via $\mathrm{NO}_{2}$-to-NO conversion within the ice bath water trap. The new sampling system showed little signs of interference from the $\mathrm{SO}_{2}$, perhaps due to the small size of its water trap. 

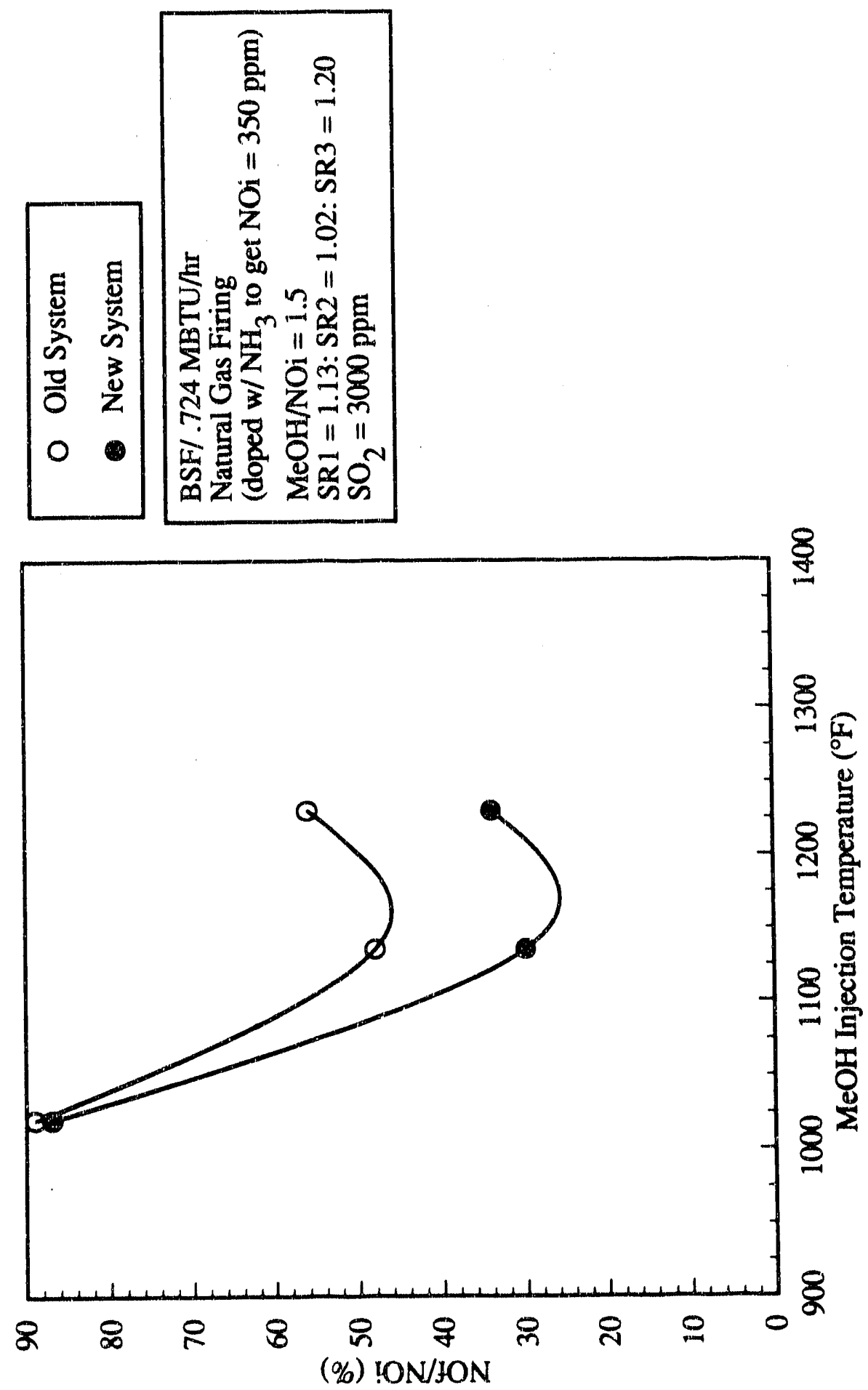

䓌 

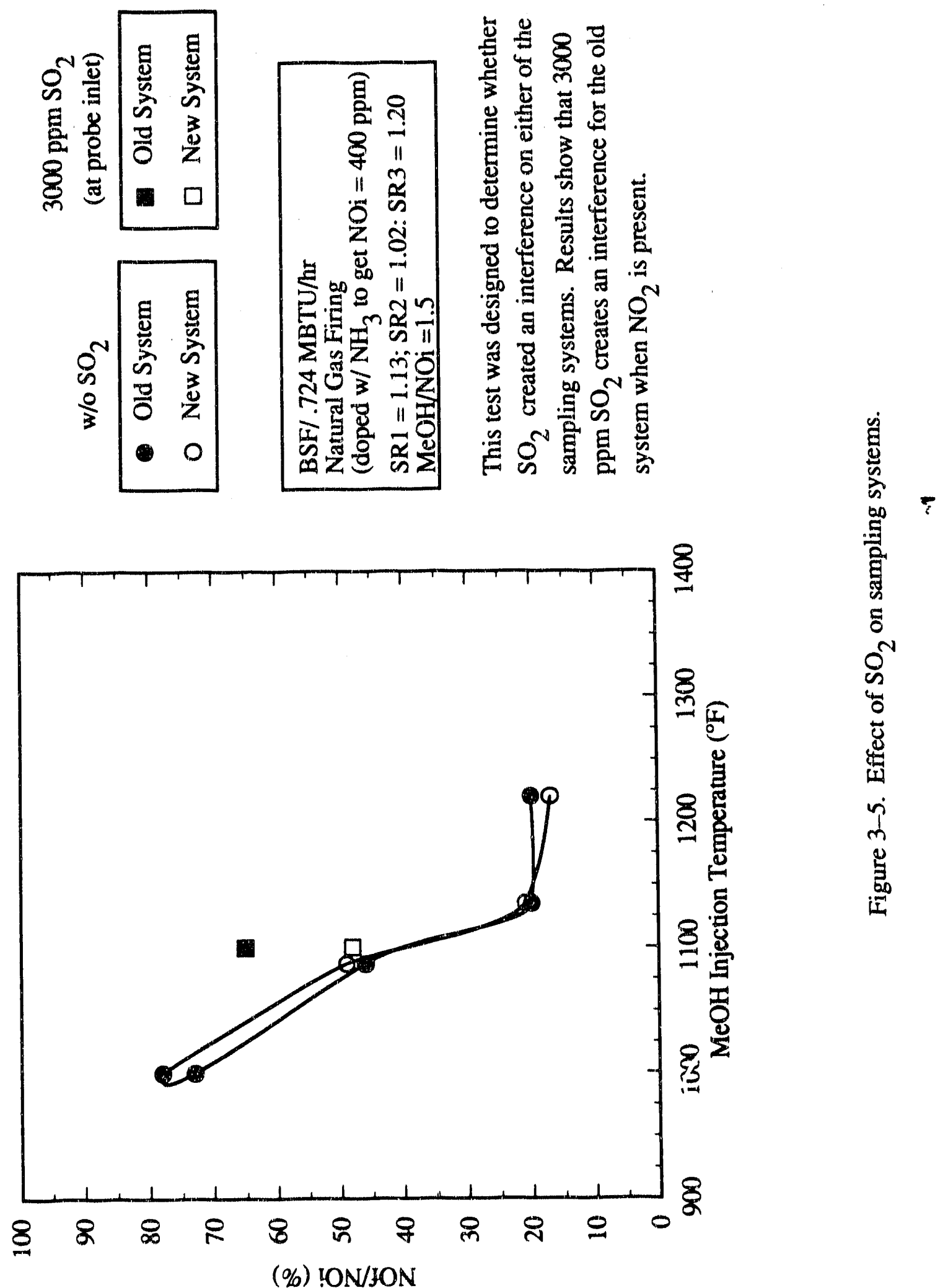


\section{Coal Fired Flue Gas}

When injecting methanol into coal fired flue gas, it was expected that the old sampling system would measure lower $\mathrm{NO}$ conversions than the new due to the $\mathrm{SO}_{2}$ interference discussed above. In actuality, the opposite occurred. NO conversion due to methanol injection was measured to be worse with the new sampling system than with the standard (see Figure 3-6). It was suggested that ash (or activated carbon) build-up within the filter in the new system could be converting the $\mathrm{NO}_{2}$ back to NO, causing the new sample system to measure a lower NO conversion. For the standard sample system, the gas sample flows through the water trap before the filter, therefore all $\mathrm{NO}_{2}$ is removed before in the sample comes in contact with the ash build-up. This eliminates the $\mathrm{NO}_{2}$-to-NO conversion within the standard system.

This theory was tested while firing natural gas on the BSF. NO/NO with a clean filter before and after methanol injection to determine baseline values. The sample probe for the new system was then pulled out of the furnace and fed with coal ash collected from the bag-house. When a fair amount of ash was collected on the filter, the probe was returned to the furnace and $\mathrm{NO} / \mathrm{NO}_{\mathrm{x}}$ measurements were taken again, before and after methanol was injected. The results are displayed in Figure 3-7. It is apparent that the ash on the filter does convert $\mathrm{NO}_{2}$-to-NO, as suspected.

To reduce the ash build-up problem, a stainless steel phase discrimination probe was used in place of the quartz probe (stainless steel was proven satisfactory for a low ammonia system). A phase discrimination probe (displayed in Figure 3-8) is designed to reduce particulate intake into a sampling system. The sample gas travels through two $180^{\circ}$ turns before exiting the probe. In theory, only gas, no particulate, will travel through the turns. Reducing the amount of particulate build-up on the filter is intended to reduce the $\mathrm{NO}_{2}$-to-NO conversion that occurs. While burning coal, it is suggested that the filter be cleaned (and sample lines purged with $\mathrm{N}_{2}$ ) prior to any high $\mathrm{NO}_{2}$ measurements. 


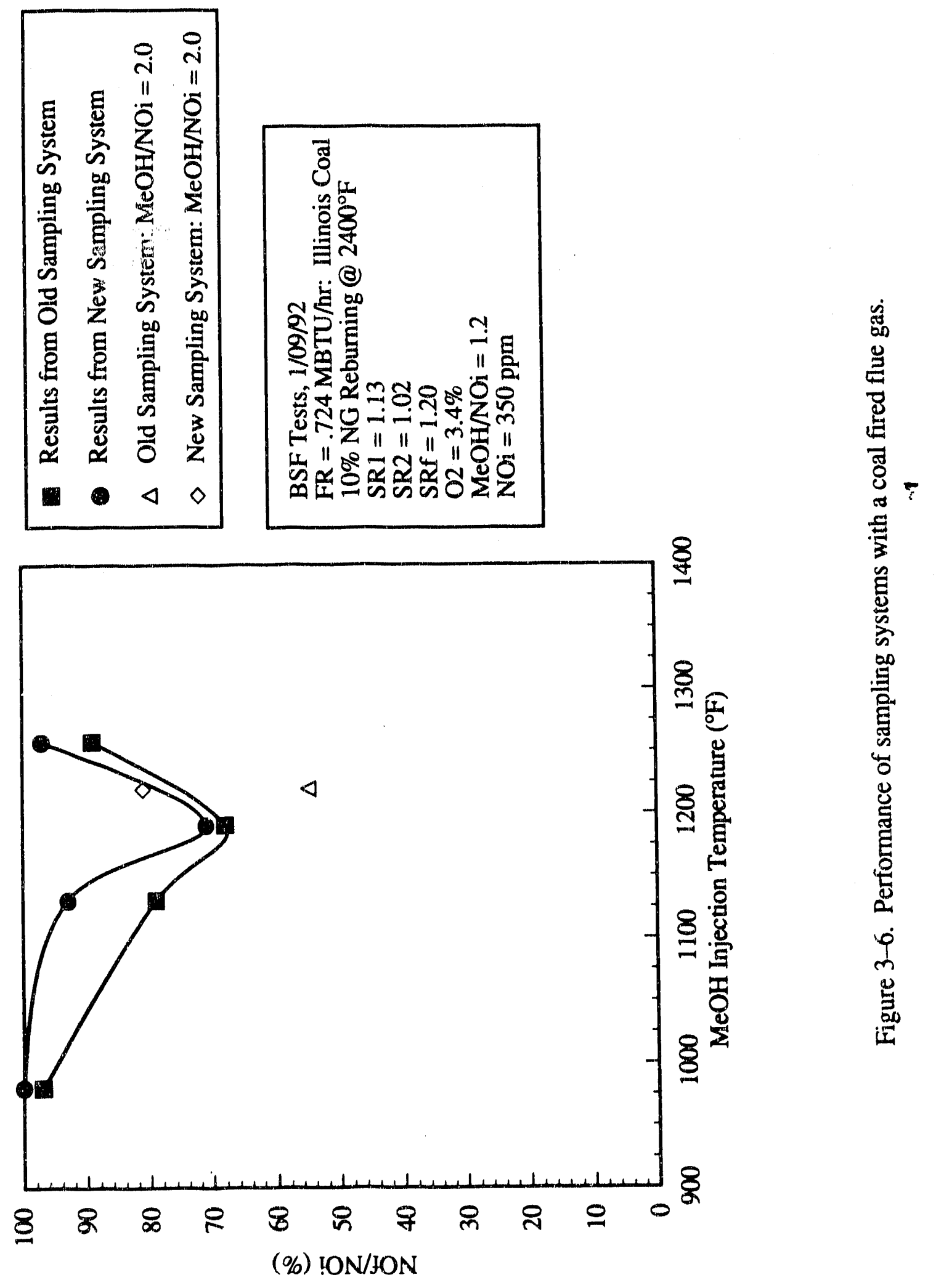




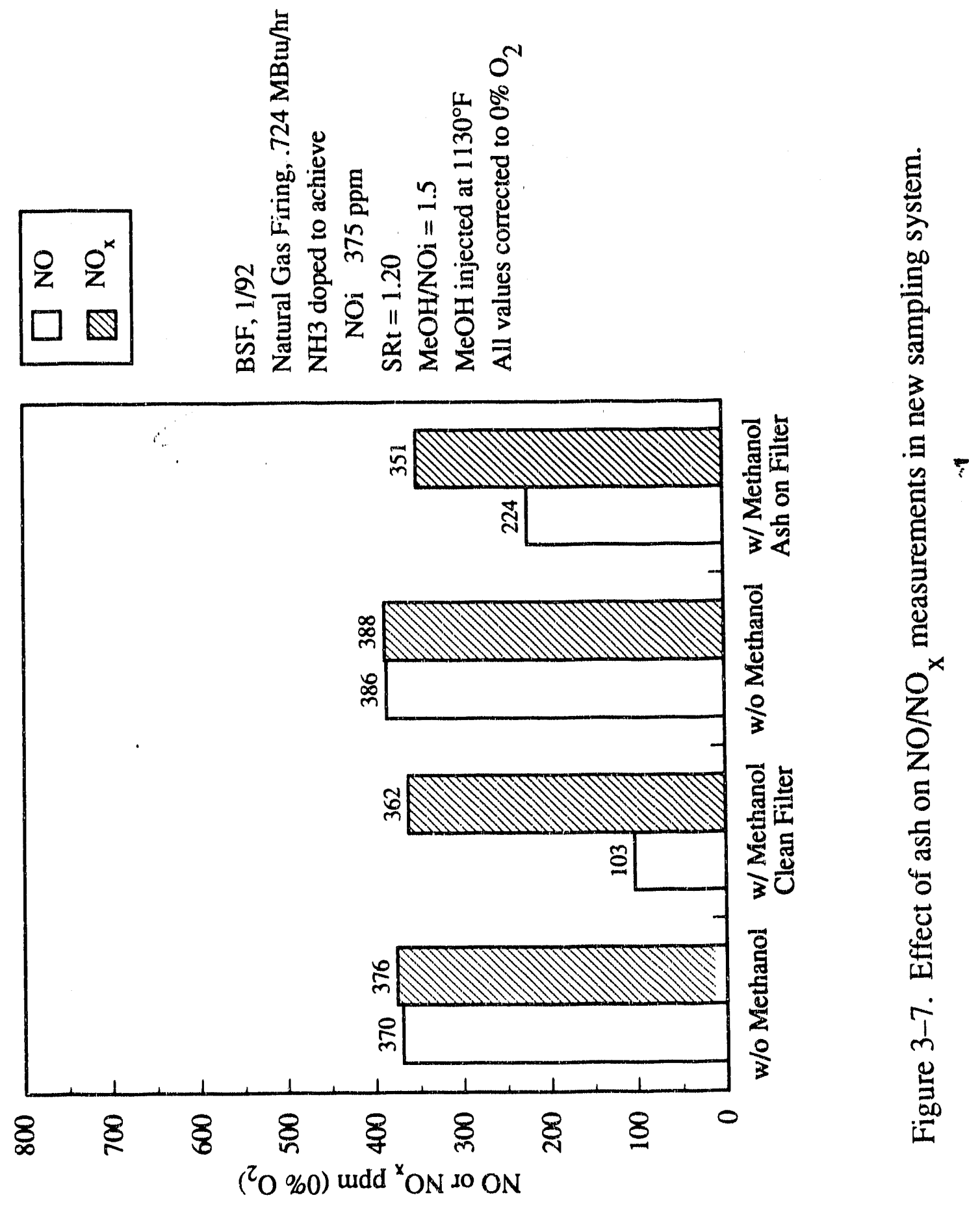




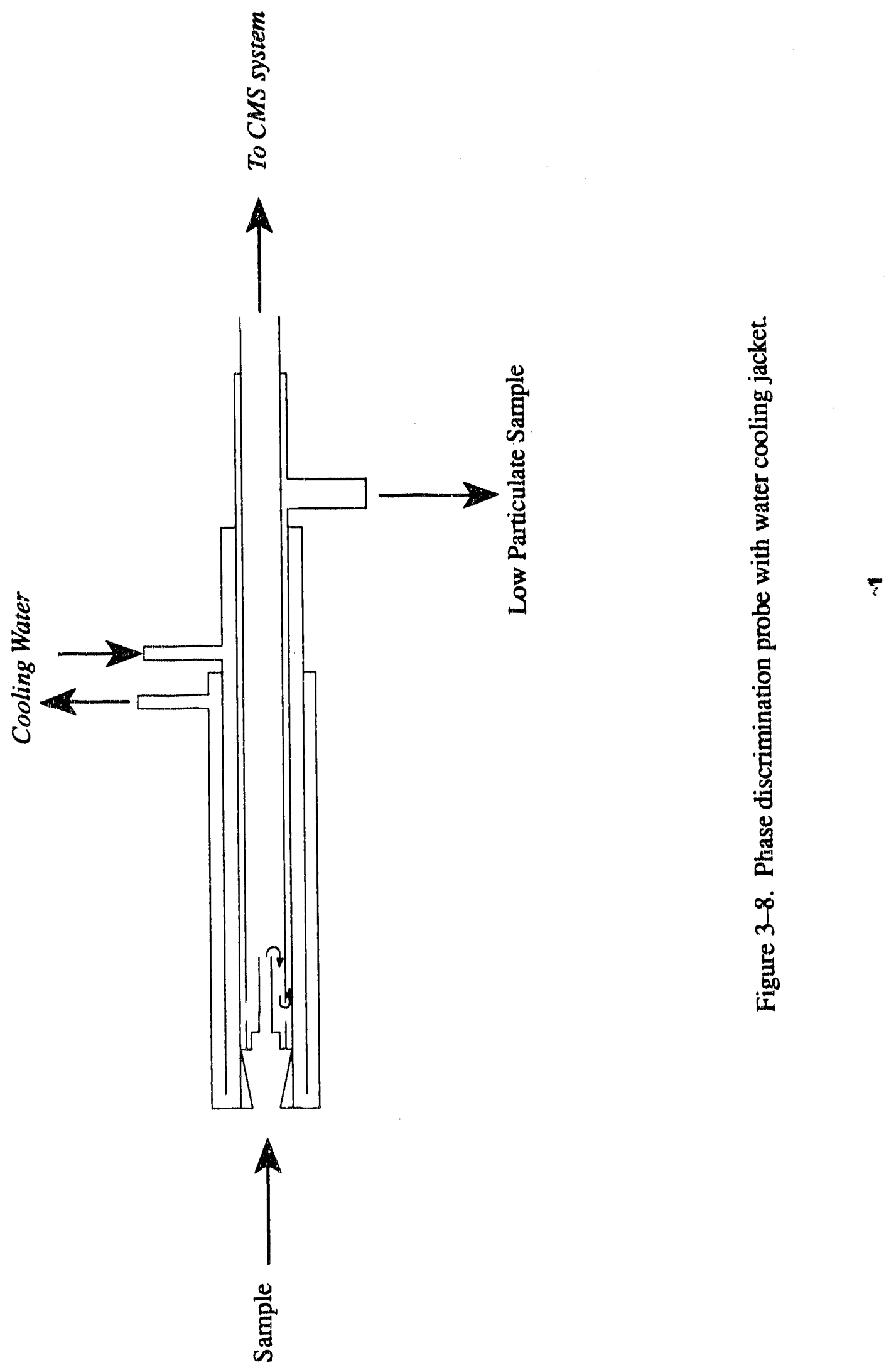




\subsection{SUMMARY}

Figure 4-1 displays the new $\mathrm{NO} / \mathrm{NO}_{\mathrm{x}}$ sampling system that was used for the remainder of the BSF tests; this system will also be used for the scale-up Reburn Tower (10 MMBtu/hr furnace) tests.

Since the stainless steel within the sampling system was found to have no effect on the $\mathrm{NO} / \mathrm{NO}_{\mathrm{x}}$ measurements, the recommended quartz probe was replaced with a stainless steel phase discrimination probe. This probe will reduce particulate intake into the sampling system, however a frequent filter change will still be necessary. The $\mathrm{NO}_{2}$-to-NO converter (in this case a carbon converter) was moved external to the $\mathrm{NO}_{\mathrm{x}}$ analyzer and prior to the water trap; this will prevent $\mathrm{NO}_{2}$ loss when water is removed. All lines must be kept above $200^{\circ} \mathrm{F}$ before the converter to prevent condensation, and to ultimately prevent $\mathrm{NO}_{2}$ losses. The sample gas must also remain below $250^{\circ} \mathrm{F}$ to avoid $\mathrm{NO}_{2}-$ to-NO conversion in the presence of the stainless steel fittings and probe.

This new system is recommended when high levels of $\mathrm{NO}_{2}$ are present. The $\mathrm{NO} / \mathrm{NO}_{\mathbf{x}}$ sampling system used in the past is suitable when measuring low $\mathrm{NO}_{2}$ concentrations. For both systems, any existing ammonia should be removed prior to the $\mathrm{NO}_{2}$-to-NO converter. 
...
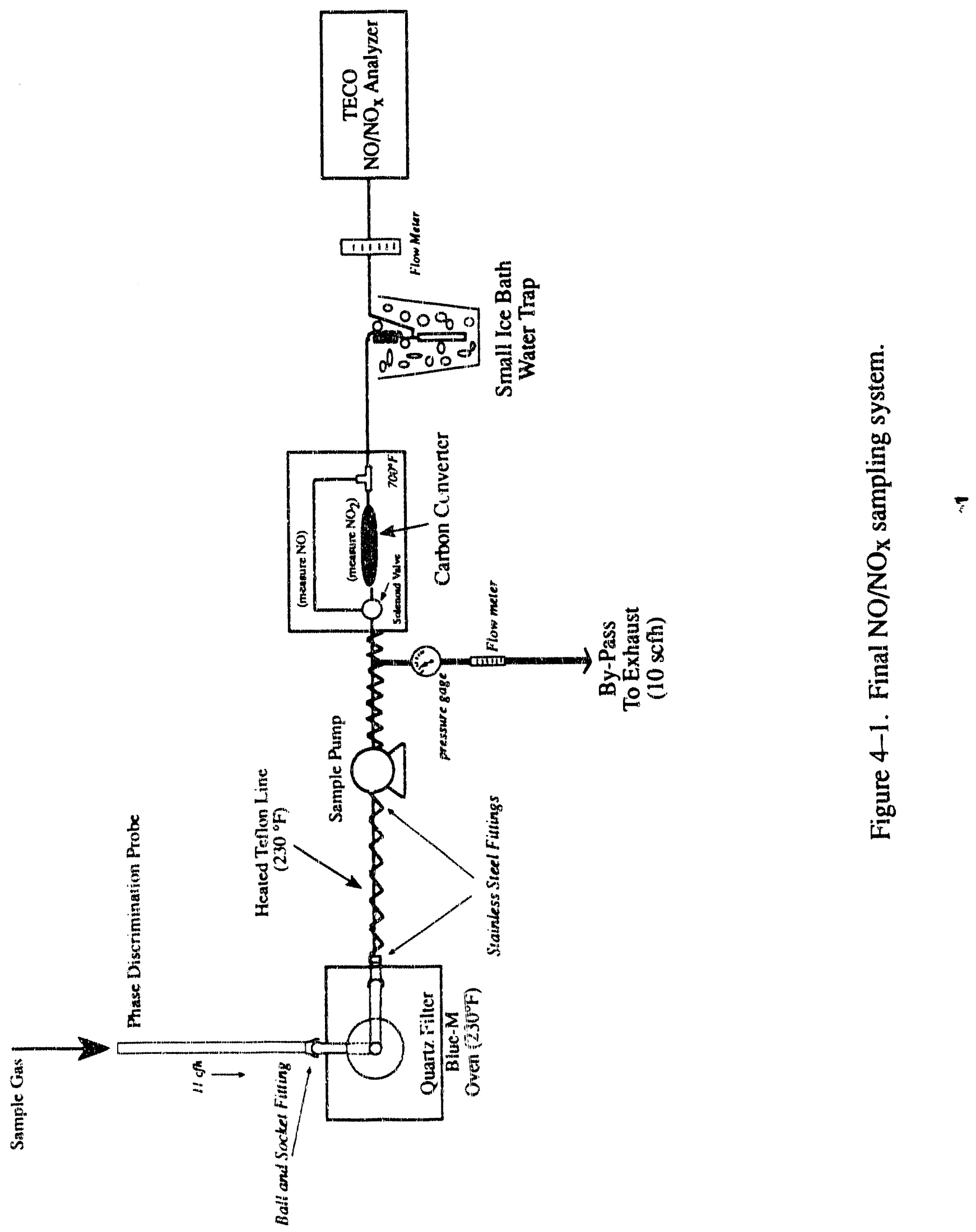

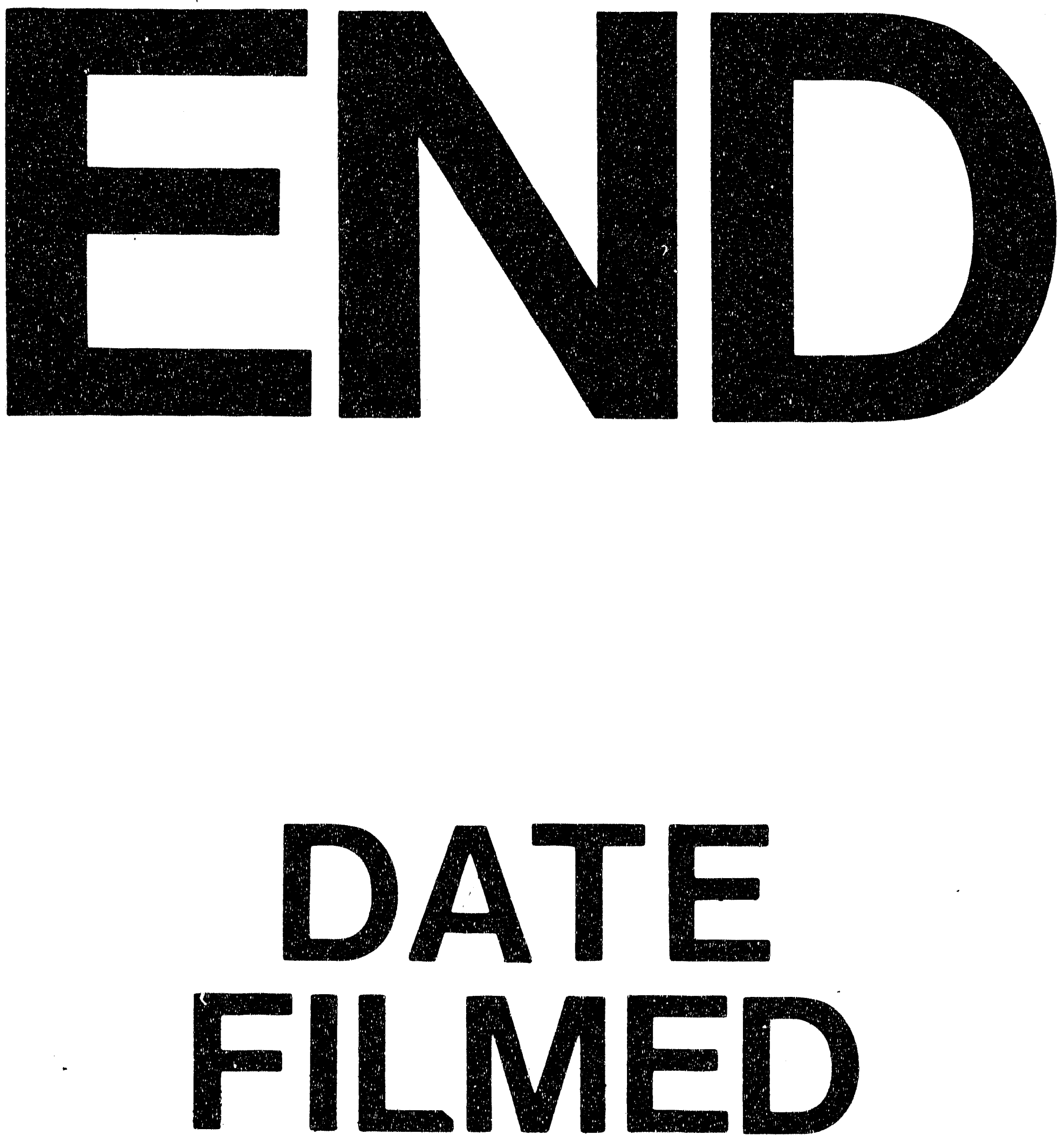

亲

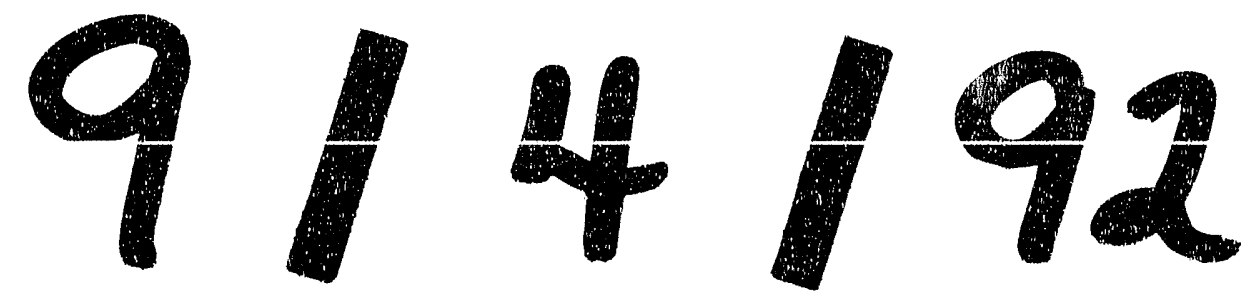


